\title{
Optical, microphysical, mass and geometrical properties of aged volcanic particles observed over Athens, Greece, during the Eyjafjallajökull eruption in April 2010 through synergy of Raman lidar and sunphotometer measurements
}

\author{
P. Kokkalis ${ }^{1}$, A. Papayannis ${ }^{1}$, V. Amiridis ${ }^{2}$, R. E. Mamouri ${ }^{1,3}$, I. Veselovskii ${ }^{4}$, A. Kolgotin $^{4}$, G. Tsaknakis ${ }^{1}$, \\ N. I. Kristiansen ${ }^{5}$, A. Stohl $^{5}$, and L. Mona ${ }^{6}$ \\ ${ }^{1}$ National Technical University of Athens, Physics Department, Laser Remote Sensing Laboratory, 15780 Zografou, Greece \\ ${ }^{2}$ Inst. for Astronomy, Astrophysics, Space Applications and Remote Sensing, National Observatory of Athens, Athens, Greece \\ ${ }^{3}$ Department of Civil Engineering and Geomatics, Cyprus University of Technology, Lemessos, Cyprus \\ ${ }^{4}$ Physics Instrumentation Center of General Physics Institute, Troitsk, Moscow 142190, Russia \\ ${ }^{5}$ Norwegian Institute for Air Research, Kjeller, Norway \\ ${ }^{6}$ Consiglio Nazionale delle Ricerche - Istituto di Metodologie per l'Analisi Ambientale, \\ C. da S. Loja, 85050 Tito Scalo, Potenza, Italy
}

Correspondence to: A. Papayannis (apdlidar@central.ntua.gr)

Received: 30 December 2012 - Published in Atmos. Chem. Phys. Discuss.: 25 February 2013

Revised: 31 July 2013 - Accepted: 8 August 2013 - Published: 17 September 2013

\begin{abstract}
Vertical profiles of the optical (extinction and backscatter coefficients, lidar ratio and Ångström exponent), microphysical (mean effective radius, mean refractive index, mean number concentration) and geometrical properties as well as the mass concentration of volcanic particles from the Eyjafjallajökull eruption were retrieved at selected heights over Athens, Greece, using multi-wavelength Raman lidar measurements performed during the period 21-24 April 2010. Aerosol Robotic Network (AERONET) particulate columnar measurements along with inversion schemes were initialized together with lidar observations to deliver the aforementioned products. The well-known FLEXPART (FLEXible PARTicle dispersion model) model used for volcanic dispersion simulations is initiated as well in order to estimate the horizontal and vertical distribution of volcanic particles. Compared with the lidar measurements within the planetary boundary layer over Athens, FLEXPART proved to be a useful tool for determining the state of mixing of ash with other, locally emitted aerosol types. The major findings presented in our work concern the identification of volcanic particles layers in the form of filaments after 7-day transport from the volcanic source (approximately $4000 \mathrm{~km}$ away from our site) from the surface and up to $10 \mathrm{~km}$ according to the
\end{abstract}

lidar measurements. Mean hourly averaged lidar signals indicated that the layer thickness of volcanic particles ranged between 1.5 and $2.2 \mathrm{~km}$. The corresponding aerosol optical depth was found to vary from 0.01 to 0.18 at $355 \mathrm{~nm}$ and from 0.02 up to 0.17 at $532 \mathrm{~nm}$. Furthermore, the corresponding lidar ratios $(S)$ ranged between 60 and $80 \mathrm{sr}$ at $355 \mathrm{~nm}$ and 44 and $88 \mathrm{sr}$ at $532 \mathrm{~nm}$. The mean effective radius of the volcanic particles estimated by applying inversion scheme to the lidar data found to vary within the range $0.13-0.38 \mu \mathrm{m}$ and the refractive index ranged from $1.39+0.009 i$ to $1.48+$ $0.006 i$. This high variability is most probably attributed to the mixing of aged volcanic particles with other aerosol types of local origin. Finally, the LIRIC (LIdar/Radiometer Inversion Code) lidar/sunphotometric combined inversion algorithm has been applied in order to retrieve particle concentrations. These have been compared with FLEXPART simulations of the vertical distribution of ash showing good agreement concerning not only the geometrical properties of the volcanic particles layers but also the particles mass concentration. 


\section{Introduction}

The eruption of the Eyjafjallajökull volcano in Iceland (April and May 2010) created unprecedented disruption to the European air traffic, costing the aviation industry an estimated EUR 200 million per day (Harris et al., 2012). Eyjafjallajökull's $\left(63^{\circ} 38^{\prime} \mathrm{N}, 19^{\circ} 36^{\prime} \mathrm{W}, 1666 \mathrm{~m}\right.$ above sea level - a.s.l.) eruption started on 14 April and ended around 19 May 2010 (Sanderson, 2010; Showstack, 2010). At 01:15 UTC on 14 April 2010 the Eyjafjallajökull's eruption plume was first visible over the volcanic site during the morning hours of that day, which a few hours later reached heights of about 10-11 km a.s.l. (Stohl et al., 2011). These height levels remained for the following days, while between 21 and 22 April, the volcanic particles plume reached lower heights (below $3 \mathrm{~km}$ a.s.l.). The total mass of the volcanic particles emitted from this eruption was estimated to be on the order of $11.9 \pm 5.9 \mathrm{Tg}$ (Stohl et al., 2011), while the injection heights were found to be often on the order of 6-7 km, reaching even heights of 9-10 km (Emeis et al., 2011; Kaminski et al., 2011; Stohl et al., 2011; Mona et al., 2012a).

The Eyjafjallajökull eruption was followed by scientists over Europe using a plethora of instruments, starting from ground-based, airborne and spaceborne platforms. However, satellite imagery was used to identify the plume dispersion and transportation, while dedicated scientific research flights enabled in situ monitoring and characterization in terms of the chemical composition of the volcanic particles (Ansmann et al., 2010, 2011; Flentje et al., 2010; Sanderson, 2010; Bukowiecki et al., 2011; Dacre et al., 2011; Gasteiger et al., 2011; Schumann et al., 2011; Carboni et al., 2012; Chazette et al., 2012; Devenish et al., 2012; Gross et al., 2012; Lettino et al., 2012; Matthias et al., 2012; Millington et al., 2012; Prata and Prata, 2012; Rauthe-Schöch et al., 2012; Schleicher et al., 2012; Webley et al., 2012; Winker et al., 2012).

However, except the in situ airborne measurements, few other techniques could provide exact volcanic particle concentrations aloft. One such technique that became very useful during the Eyjafjallajökull eruption is the laser remote sensing (lidar) technique, which is a very favorable tool for the direct monitoring of the vertical profile of the aerosol optical properties. Besides the aerosol optical properties, one can estimate the volcanic aerosol geometrical and microphysical properties, as well as the volcanic particle concentration (Ansmann et al., 2010, 2011, 2012; Gasteiger et al., 2011; Chazette et al., 2012; Papayannis et al., 2012; Wiegner et al., 2012). The lidar technique was employed throughout Europe in the frame of the EARLINET project (Bösenberg et al., 2003) to monitor the volcanic particles plume dispersion - in time and space - over the European continent (Ansmann et al., 2010, 2012; Emeis et al., 2011; Gasteiger et al., 2011; Gross et al., 2012; Mona et al., 2012a; Papayannis et al., 2012; Revuelta et al., 2012; Rolf et al., 2012; Trickl et al., 2012; Wiegner et al., 2012; Navas-Guzmán et al., 2013; Pappalardo et al., 2013).
In this paper, the volcanic particles measurements performed at the EARLINET station of Athens during the period 21-24 April 2010 are presented. The focus of this paper is on the study and characterization of the mixing of aged volcanic particles with other aerosol types of local origin. The instrumentation used is briefly described in Sect. 2, and our results for a selected case study are presented and analyzed in Sect. 3. Finally, our summary and conclusions are presented in Sect. 4.

\section{Instrumentation and methods}

\subsection{The Raman lidar system}

In Athens, Greece, the multi-wavelength lidar system EOLE is operating at the National Technical University of Athens (NTUA, $37.97^{\circ} \mathrm{N}, 23.79^{\circ} \mathrm{E}, 220 \mathrm{~m}$ a.s.l.) as part of EARLINET (European AeRosol LIdar NETwork) (Bösenberg et al., 2003) and has been quality assured in the framework of network's activities through direct inter-comparisons, both at hardware (Matthias et al., 2004) and algorithm levels (Böckmann et al., 2004; Pappalardo et al., 2004). A complete technical description is provided by Kokkalis et al. (2012).

The lidar signals detected at 355, 387, 532, 607 and $1064 \mathrm{~nm}$ were used to derive the aerosol backscatter (at 355, 532 and $1064 \mathrm{~nm}$ ) and extinction (at 355 and $532 \mathrm{~nm}$ ) coefficients, as well as the Ångström exponent (AE) profiles, while the $407 \mathrm{~nm}$ channel was used to derive the water vapor mixing ratio (Mamouri et al., 2008). In order to qualitatively retrieve the aerosol optical properties with a lidar system, several techniques have to be combined. Thus, the Klett inversion technique (Klett, 1985), with the assumptions of a reference height in an aerosol-free region (e.g., the upper troposphere) and a constant extinction-to-backscatter ratio (the so-called lidar ratio, $S$ ) value, is used to retrieve the atmospheric profile of the aerosol backscatter coefficient $\left(b_{\text {aer }}\right)$ at the wavelengths of interest. The retrieved $b_{\text {aer }}$ values have an average uncertainty (due to both statistical and systematic errors) on the order of 20-30 \% (Bösenberg et al., 1997).

When using the Raman technique (Ansmann et al., 1992), the uncertainties associated with the retrieved aerosol extinction coefficient $\left(a_{\text {aer }}\right)$ and $b_{\text {aer }}$ vertical profiles are mainly due to the presence of noise on the received lidar signal. In this case the systematic uncertainties are on the order of 5-15\% on the $b_{\text {aer }}$ and of 10-25\% on the $a_{\text {aer }}$ (Ansmann et al., 1992; Mattis et al., 2002). Thus, with the Raman technique, the vertical profile of the aerosol parameter $S$ can be calculated and not assumed, with a corresponding systematic uncertainty on the order of $5-10 \%$.

\subsection{The AERONET station}

Our sunphotometric observations were performed with a ground-based CIMEL sun-sky radiometer (Holben et al., 1998), which is part of the Aerosol Robotic Network 
(AERONET) global network (http://aeronet.gsfc.nasa.gov). The instrument located on the roof of the Research Centre for Atmospheric Physics and Climatology of the Academy of Athens $\left(37.99^{\circ} \mathrm{N}, 23.78^{\circ} \mathrm{E}, 130 \mathrm{~m}\right.$ a.s.l.) is operated by the Institute for Astronomy, Astrophysics, Space Applications and Remote Sensing of the National Observatory of Athens (NOA). The photometer data used in this study are level 2.0, and provide information about the columnar aerosol optical depth (AOD) at standard wavelengths (340, 380, 440, 500, 675, 870, 940 and $1020 \mathrm{~nm}$ ), the Ångström exponent (AE), the aerosol size distribution and the aerosol microphysical properties (Holben et al., 1998). The AERONET data products along with the technical specifications and the uncertainties of the CIMEL instrument are given in detail in Holben et al. (1998). More specifically, the total uncertainty of the $\mathrm{AOD}$ and the AE is influenced by various instrumental, calibration, atmospheric and methodological factors; the AOD uncertainty is $< \pm 0.01$ for wavelengths longer than $440 \mathrm{~nm}$ and $< \pm 0.02$ for UV wavelengths (Eck et al., 1999), or about $10 \%$ for a nominal aerosol optical depth of 0.1 . The uncertainty of the sky radiance data and the resulting aerosol size distributions are determined based on the calibration uncertainty that is assumed $< \pm 5 \%$ at all four wavelength channels (Holben et al., 1998).

\subsection{FLEXPART dispersion model}

To simulate the volcanic particle transportation, we employed the widely used Lagrangian particle dispersion model FLEXPART (FLEXible PARTicle dispersion model) (Stohl et al., 1998, 2005). The simulations are based on the initial release of a large number of virtual particles, following the mean winds with superimposed random motions representing turbulence and convection. The model takes into account also the particles' physical processes such as sedimentation and dry and wet deposition. The meteorological fields used in this study as input in FLEXPART model are taken from the European Centre for Medium-Range Weather Forecasts (ECMWF) with a horizontal resolution of $0.18^{\circ} \times 0.18^{\circ}$ and 91 vertical levels. The output resolution in the horizontal and vertical level was set to be $0.25^{\circ} \times 0.25^{\circ}$ and $250 \mathrm{~m}$, respectively, with the latter consisting of 38 vertical levels.

The major assumption - the strength of the initially injected volcanic ash - was determined by an inversion algorithm (Stohl et al., 2011). The aforementioned algorithm uses satellite data in order to constrain the emissions of the ash that was modeled. In general the FLEXPART simulation follows the scenario that 21 million particles were released from the volcano. Those particles were categorized into 25 classes depending on their diameter ranging between 0.25 and $250 \mu \mathrm{m}$. However, only volcanic particles linked with diameters up to $10 \mu \mathrm{m}$ could reach the lidar stations in Europe after several days of advection, due to the fact that the larger ones mostly fall out by gravitational settling (Näslund and Thaning, 1991), especially close to the source. More information on FLEXPART can be found at http://transport.nilu.no/flexpart, and the model results used here are described in detail in Stohl et al. (2011), with further evaluations provided by Kristiansen et al. (2012).

\subsection{LIRIC aerosol inversion code}

The LIRIC (LIdar/Radiometer Inversion Code) algorithm has been developed within ACTRIS (Aerosols, Clouds and Trace gases Research InfraStructure Network - www.actris. net) by the Institute of Physics in Minsk (Belarus) in collaboration with the Laboratoire d'Optique Atmosphérique, Lille (France). LIRIC calculates the fine- and coarse-particle concentration profiles, utilizing the backscattered lidar signals (at 355, 532 and $1064 \mathrm{~nm}$ ) and the column-averaged aerosol microphysical properties retrieved from a sunphotometer. Moreover, if the cross-polarized measurement at $532 \mathrm{~nm}$ is provided, the algorithm has the capability to differentiate the coarse-mode concentration into spherical and nonspherical components. For the aforementioned calculations, the assumption is made that except for the concentration, all other particle properties are constant along the atmospheric column and equal to the column-averaged values provided by the sunphotometer. The retrieval is based on a maximum-likelihood estimation of the concentration profiles so that the lidar signals are reproduced within their measurement uncertainty and the integral of the retrieved aerosol concentrations matches the total volume concentration of the fine and coarse modes derived from sunphotometric measurements.

Furthermore, in order to avoid any unphysical values, smoothing constraints are imposed on the retrieved concentration profiles. A detailed description of LIRIC can be found in Chaikovsky et al. $(2004,2012)$ and Tsekeri et al. (2013). LIRIC provides the aerosol concentration profiles $\left(C_{\mathrm{f} / \mathrm{c}}(z)\right)$, which are expressed in parts per billion volume (ppbv), or equivalently, the volume of aerosol particles in a unit volume of air (expressed in $1000 \mu \mathrm{m}^{3} \mathrm{~cm}^{-3}$ ). For the conversion of volume to mass concentration $\left(m_{\mathrm{f} / \mathrm{c}}(z)\right.$, expressed in $\mu \mathrm{g} \mathrm{m}^{-3}$ ), the following equation is used:

$m_{\mathrm{f} / \mathrm{c}}(z)=\rho_{\mathrm{f} / \mathrm{c}} \times C_{\mathrm{f} / \mathrm{c}}(z)$,

where the subscript $\mathrm{f} / \mathrm{c}$ denotes either the fine (f) or coarse (c) aerosol mode. Fine and coarse modes are assumed to be representative for sulfate and volcanic ash particles, respectively. The first term is the particle density $\left(\rho_{\mathrm{f} / \mathrm{c}}\right)$, and for our case the values for fine and coarse particles were 1.5 and $2.6 \mathrm{~g} \mathrm{~cm}^{-3}$, respectively (http://volcanoes.usgs.gov/ volcanicparticles/properties.html/density, Schumann et al., 2011; Bukowiecki et al., 2011). The second term is the LIRIC concentration profile $C_{\mathrm{f} / \mathrm{c}}(z)$ for aerosol fine and coarse modes, respectively, which is the main output of the algorithm.

Furthermore, the extinction and backscatter coefficient profiles $\left(\alpha_{\text {aer }}(\lambda, z)\right.$ and $\left.b_{\text {aer }}(\lambda, z)\right)$ are calculated from 
AERONET column-averaged extinction and backscatter coefficients $\left(\alpha_{\mathrm{f} / \mathrm{c}}(\lambda)\right.$ and $\left.b_{\mathrm{f} / \mathrm{c}}(\lambda)\right)$ multiplied by the corresponding particle concentration profiles $C_{\mathrm{f} / \mathrm{c}}(z)$, which are calculated by LIRIC:

$a_{\mathrm{aer}}(\lambda, z)=a_{\mathrm{f}}(\lambda) \times C_{\mathrm{f}}(z)+a_{\mathrm{c}}(\lambda) \times C_{\mathrm{c}}(z)$,

$b_{\text {aer }}(\lambda, z)=b_{\mathrm{f}}(\lambda) \times C_{\mathrm{f}}(z)+b_{\mathrm{c}}(\lambda) \times C_{\mathrm{c}}(z)$.

\subsection{Methodology on the derivation of the aerosol microphysical properties}

The measured vertical profiles of the $a_{\mathrm{aer}}$ and $b_{\mathrm{aer}}$ at multiple wavelengths can be converted to the profiles of the particle microphysical parameters by using the regularization technique (Müller et al., 1999; Veselovskii et al., 2002, 2009). However, the application of this multi-wavelength (MW) lidar technique to aerosol dust data meets certain obstacles. Usually, all current lidar algorithms treat aerosols as an ensemble of spherical particles. However, it is well established that backscattering by irregularly shaped particles is weaker than by spheres of equivalent volume. To overcome these problems, Mishchenko et al. (1997) suggested to model the irregularly shaped particles with a mixture of polydisperse, randomly oriented spheroids, and showed that mixture of such simplified particles can mimic the properties of natural nonspherical aerosols.

Similarly, Dubovik et al. (2006) included the spheroid model in the AERONET retrieval algorithm. The same concept was later adopted by Veselovskii et al. (2010) for the incorporation of a spheroid model into the lidar retrieval of dust particles physical properties: in this case aerosols are modeled as a mixture of spheres and randomly oriented spheroids with a size-independent shape distribution. This technique was further applied to derive bulk aerosol properties from multi-wavelength Raman lidar measurements (Veselovskii et al., 2012). The results of numerical simulations demonstrate that for $10 \%$ uncertainty of input optical data $\left(a_{\mathrm{aer}}\right.$ and $\left.b_{\mathrm{aer}}\right)$, the particle volume density $(V)$, and the effective radius $\left(r_{\text {eff }}\right)$ can be estimated with an accuracy better than $30 \%$; however the retrieval of the particle number density (NC) is normally characterized by a higher uncertainty, which can reach up to $50 \%$. The use of the regularization technique allows also the estimation of the particle complex refractive index (CRI), where the real part of CRI $\left(m_{\mathrm{R}}\right)$ can be estimated with an accuracy of \pm 0.05 . The imaginary part of CRI $\left(m_{\mathrm{I}}\right)$ is one of the most difficult parameters to retrieve, where for $m_{\mathrm{I}}>0.005$ the corresponding uncertainty is $50 \%$.

In this paper the aerosol microphysical properties $\left(r_{\mathrm{eff}}\right.$, $\left.\mathrm{NC}, m_{\mathrm{R}}, m_{\mathrm{I}}\right)$ inside the volcanic particles' layers in the lower free troposphere were retrieved using the regularization approach provided by Veselovskii et al. (2002), using as input the optical data obtained from our Raman MW lidar measurements. To account for the particle non-sphericity, the model of randomly oriented spheroids was used, as described in Veselovskii et al. (2010). Our recent experience gained during processing of desert dust lidar measurements (Müller et al., 2013) demonstrates that, for particle depolarization ratio values exceeding $25 \%$, it is better to perform the inversion using the spheroidal kernels only, and thus the set of input data in this study included three particle backscattering and two extinction coefficients. The inverse problem in our formulation is underdetermined, so additional constraints should be applied. Specifically, we limited the range of considered parameters as follows: the particle radii were limited by the interval $0.075-15 \mu \mathrm{m}$; the $m_{\mathrm{R}}$ and $m_{\mathrm{I}}$ were searched inside $1.35-1.65$ and $0-0.02$ intervals, respectively. The particle bulk properties, such as $V, \mathrm{NC}$ and $r_{\text {eff }}$, were calculated from the total particle size distribution.

\section{Eyjafjallajökull ash advection over Greece}

In this section, the advection of Eyjafjallajökull volcanic ash over Greece is described and analyzed by means of lidar and synergetic measurements/model simulations for the period between 20 and 24 April 2010. These data were collected in a dedicated relational database available on request at the EARLINET website.

\subsection{Ash dispersion and geometrical characteristics}

Volcanic particles ejected during the Eyjafjallajökull April 2010 eruption covered major parts of central Europe only about two days after the eruption onset (e.g., Ansmann et al., 2010; Emeis et al., 2011; Devenish et al., 2012), while southern southeastern Europe was affected at a later stage (Papayannis et al., 2012). According to FLEXPART dispersion model simulations shown in Fig. 1 and as has been reported by studies performed in southern Europe on April 2010 (e.g., Mona et al., 2012a; Papayannis et al., 2012), the period of strong advection was centered between 20 and 24 April. As FLEXPART simulations indicate on 20 April (00:00 to 12:00 UTC), remainders of the volcanic ash ejected earlier still covered central Europe (total columnar concentrations up to $800-900 \mathrm{mg} \mathrm{m}^{-2}$ ) and northern Italy, and slowly reached eastern Europe as well. On the following day (21 April, at 00:00 UTC), the ash cloud moved more clearly southeastward, with bulk total columnar concentrations ranging between 200 and $700-800 \mathrm{mg} \mathrm{m}^{-2}$ over the Balkans area. Later on the same day (12:00 UTC) and on 22 April (00:00 UTC) the ash cloud passed over Greece, where maximum columnar concentrations on the order of $200-400 \mathrm{mg} \mathrm{m}^{-2}$ were simulated. Finally, the event started to fade out during the following days, from 22 (12:00 UTC) to 24 April (00:00 UTC), for which very low concentrations $\left(<50 \mathrm{mg} \mathrm{m}^{-2}\right)$ are indicated by FLEXPART over southeastern Europe, northern Africa and Cyprus.

To summarize, according to the FLEXPART simulations, Greece was mainly affected by volcanic particles between 21 (12:00 UTC) and 24 April (00:00 UTC), but traces of ash were simulated already from 20 April (between 

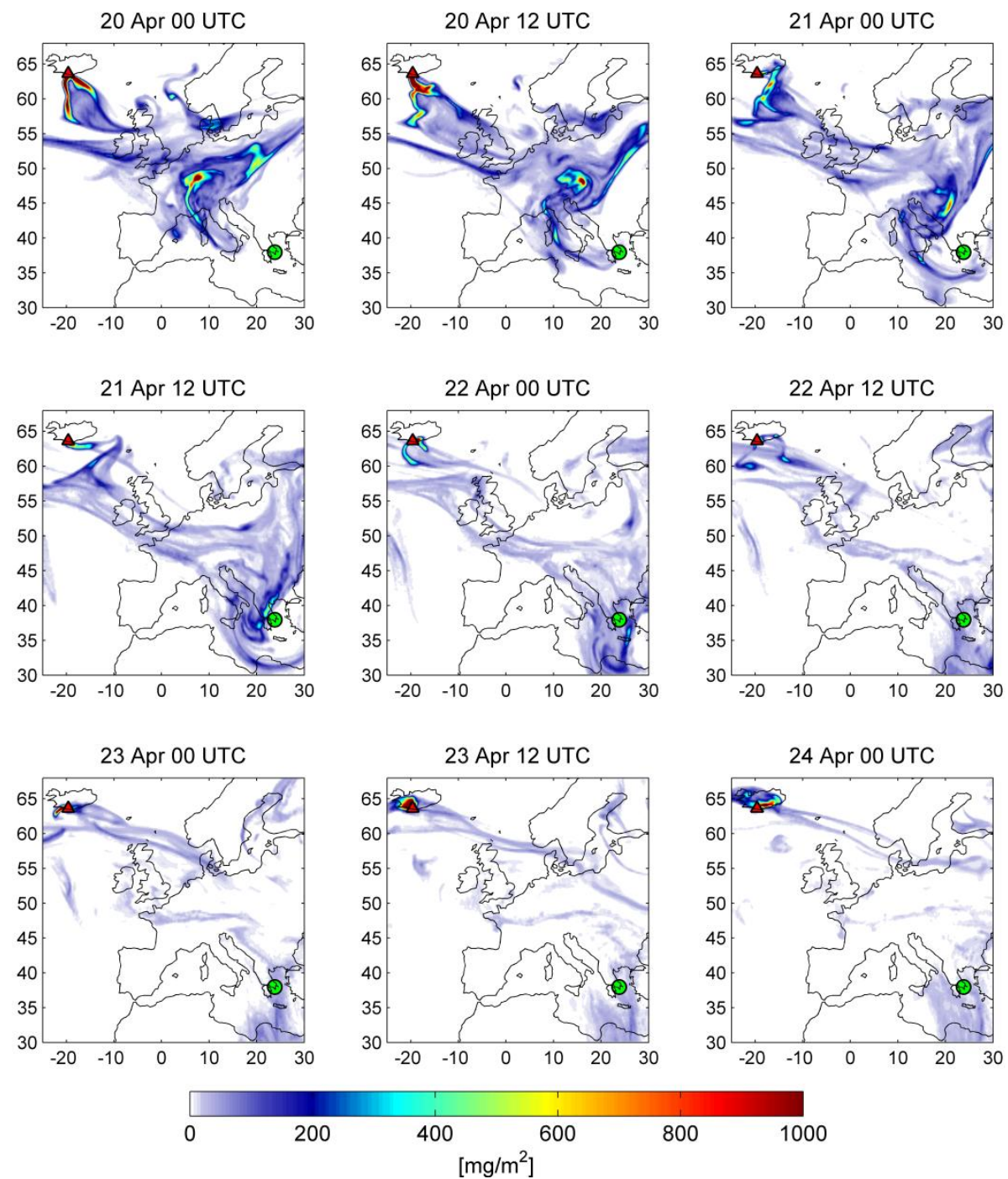

Fig. 1. FLEXPART simulations of the Eyjafjallajökull volcanic ash dispersion (total column in $\mathrm{mg} \mathrm{m}^{-2}$ for all 25 particle size classes) for the period of 20 (00:00 UTC) to 24 April 2010 (00:00 UTC). The position of the Athens lidar station is marked by a green circle, while the location of the volcano is shown by a red triangle.

00:00 and 12:00 UTC). This is also demonstrated in the time-height contours of volcanic particle concentration (in $\mu \mathrm{g} \mathrm{m}^{-3}$ ) shown in Fig. 2 (upper panel), as those simulated by FLEXPART over Athens (from 20 April 00:00 UTC to 24 April 00:000 UTC). The volcanic particles first advected over Athens in the height range between 3 and $5.5 \mathrm{~km}$ on 20 April (around 12:00 UTC) but at quite low concentrations (lower than $100 \mu \mathrm{g} \mathrm{m}^{-3}$ ). Later, on the following day (21 April), higher concentrations of volcanic particles appeared in the height range from 3.5 to $6 \mathrm{~km}$ (from 15:00 UTC up to around 21:00 UTC) with concentrations on the order of 100$400 \mathrm{\mu g} \mathrm{m}^{-3}$. Later that night, the volcanic particles (having concentrations on the order of $50 \mu \mathrm{g} \mathrm{m}^{-3}$ ) started to settle down, reaching the ground (on 22 April, around 07:00 UTC), where they most probably mixed with urban haze and local pollution.

FLEXPART simulations over Athens are qualitatively consistent with the ground-based lidar measurements for free-tropospheric ash load as shown from the comparison of Fig. 2 in upper and middle panels. The middle panel presents the temporal evolution of the range-corrected lidar signal (RCS), which shows thin aerosol layers (in the form of filaments - shown in light blue), which are first observed at $10 \mathrm{~km}$ height around 16:00 UTC on 21 April, a situation similar to that reported also by Mona et al. (2012a) over southern Italy. During that night and until 04:00 UTC on 22 April, a new advection of volcanic particles at around $4.5 \mathrm{~km}$ is depicted by the lidar measurements, which are consistent with FLEXPART simulations as well. Additional aerosol layers 

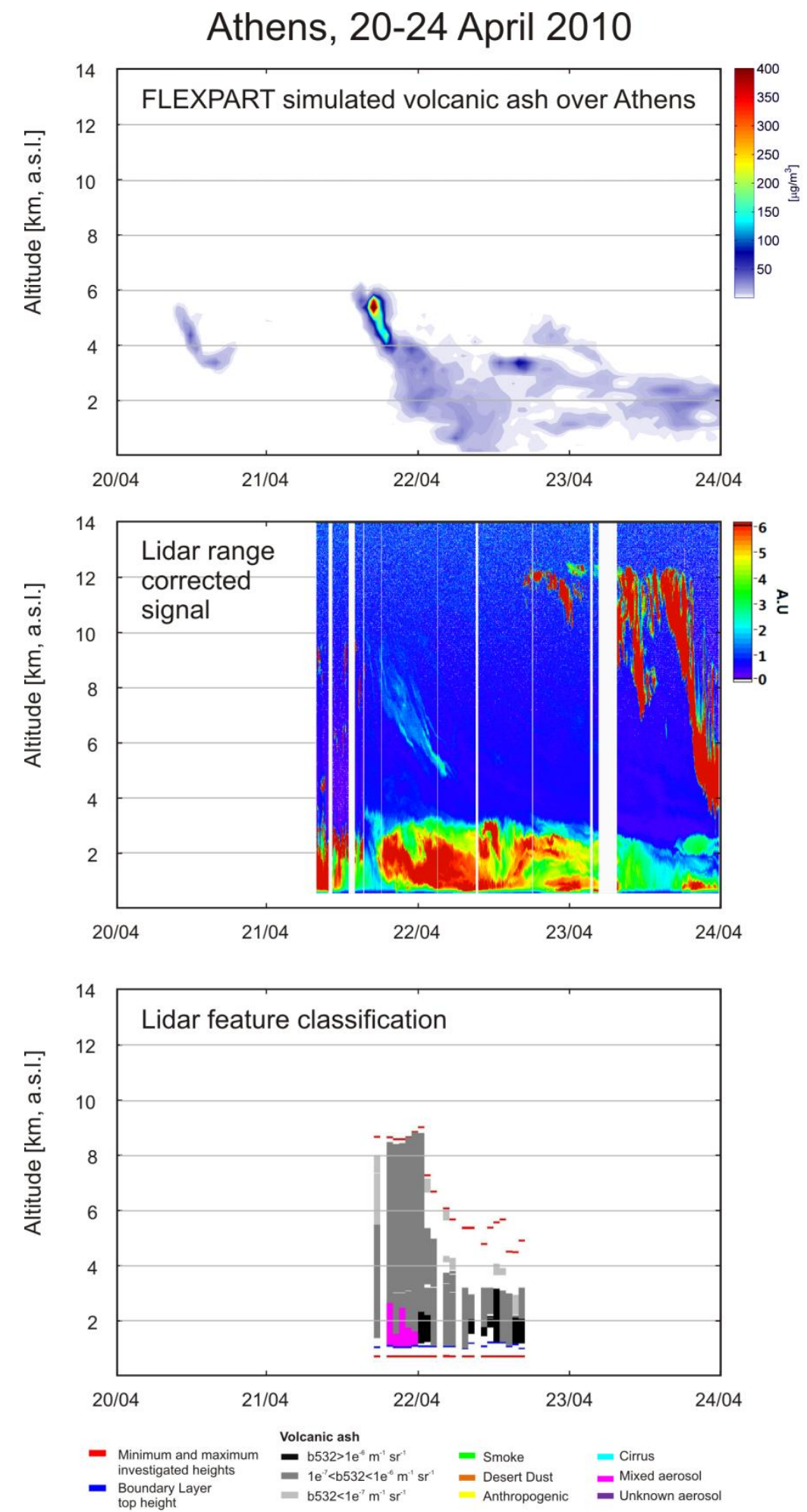

Fig. 2. (upper graph) Time-height contours of volcanic ash concentrations (in $\mu \mathrm{g} \mathrm{m}^{-3}$ ) over Athens from 20 April 2010 at 00:00 UTC to 24 April 2010 at 00:000 UTC, as simulated by FLEXPART. (middle graph) Temporal evolution of the range-corrected lidar signal (RCS) in arbitrary units (A.U.) obtained over Athens at $1064 \mathrm{~nm}$, between 21 (07:00 UTC) and 24 April 2010 (03:00 UTC). All colored structures correspond to the presence of aerosols, except after 22 April 2010 (15:00 UTC), where clouds are detected at heights between 4 and $12.5 \mathrm{~km}$. (lower graph) Aerosol masking for the particle layers detected over Athens from 21 (16:00 UTC) to 22 April 2010 (16:30 UTC). 
(shown again in light blue) were observed around 3.3 and $2 \mathrm{~km}$ height (21 April at 15:00 UTC), and finally descended into the PBL around 16:00 UTC, where the volcanic particles were most probably mixed with locally produced aerosols (shown in red, from 21 April at 16:00 UTC to 23 April at around 04:00 UTC).

This is indicated by FLEXPART in conjunction with strong aerosol loads observed by lidar within the PBL. Due to the aerosol load presence in the PBL from local anthropogenic sources, it is not trivial to distinguish volcanic ash in that mixture, especially when depolarization information is not available in order to separate the nonspherical particles from the spherical ones (e.g., Tesche et al., 2009).

However, some part of the ash layer observed around $3.3 \mathrm{~km}$ height remained well above the top of the PBL height (at around $3 \mathrm{~km}$ ) during the following days (up to 23 April at 04:00 UTC) before the volcanic particles signal fade out at lower altitudes (around $1 \mathrm{~km}$ ) on 24 April (around 03:00 UTC). A series of cirrus clouds were observed between 10 and $12 \mathrm{~km}$ height (from 22 April around 18:00 UTC to 23 April around 04:00 UTC), which show up prominently in Fig. 2 (middle panel). Later on 24 April (around 00:00 UTC), these clouds also reached much lower heights, finally reaching $3 \mathrm{~km}$. In that same figure, both aerosol layers depicted by the lidar in light blue (from 10 down to $5 \mathrm{~km}$ and around $3.5 \mathrm{~km}$ ) were associated with pure volcanic particles advected over Athens according to FLEXPART and the consistency between the model simulations and observations, especially for the free-tropospheric loads. Moreover, radiosonde measurements performed on 22 April (00:00 UTC) indicated a very dry aerosol layer with relative humidity of $10 \%$ around $8.5 \mathrm{~km}$, while it ranged from 20 to $50 \%$ between 1 and $6 \mathrm{~km}$, at heights where aerosols were observed by lidar at that time. This is most likely attributed to the ash presence.

A final procedure is applied to our lidar observations regarding the classification of layers observed in features of specific type using typical optical properties measured. Specifically, we apply the methodology developed by Mona et al. (2012a) in the frame of the EARLINET-coordinated volcanic particles measurements (Pappalardo et al., 2013). To identify the presence of these particles, Mona et al. (2012a) used aerosol-related intensive parameters (e.g., extinctionrelated Ångström exponent (EAE) and backscatter-related Ångström exponent (BAE)) retrieved by multi-wavelength Raman lidar measurements in conjunction with air mass back trajectory analysis based on the HYbrid Single-Particle Lagrangian Integrated Trajectory (HYSPLIT) code.

Prior to the aerosol "masking" procedure, an aerosolcloud discrimination scheme is applied (Mona et al., 2012a). The output classification results of the aerosol masking procedure are shown in Fig. 2 (lower panel), focused on the dates of ash advection, namely 21 and 22 April. The volcanic aerosol layers are denoted by different shades of gray, classified according to the mean value of the aerosol backscatter coefficient at $532 \mathrm{~nm}$. For the studied period, the PBL height was found to be below $2 \mathrm{~km}$ height. Therefore, from the classification, it is further supported that on 21 April (17:00 UTC), free-troposphere volcanic particles layers were observed from the top of the PBL up to $10-12 \mathrm{~km}$ height. During the afternoon hours of the same day, mixed aerosol loads were detected in the height range from 2 to $4 \mathrm{~km}$ (denoted by magenta coloring).

At the same heights, and during the early morning hours of 22 April ( 01:00 UTC), the volcanic aerosols seem to present a maximum concentration above the top of the PBL (denoted by black coloring), in terms of $b_{\text {aer }}$, which is on the order of $1 \mathrm{Mm}^{-1} \mathrm{sr}^{-1}$. During the morning and noon hours of the same day, $b_{\text {aer }}$ at $532 \mathrm{~nm}$ ranged from 0.1 to $1 \mathrm{Mm}^{-1} \mathrm{sr}^{-1}$. According to the classification scheme and synergetic model simulations (BSC-DREAM8b and HYSPLIT air mass backtrajectories) and the Moderate Resolution Imaging Spectroradiometer (MODIS) satellite data (not shown here), neither dust nor smoke was present in the PBL of Athens during these two days.

Finally, we present in this section the geometric characteristics of the ash layers over Athens. Specifically, we calculate from the lidar data the center of mass (CoM) of the aerosol layers observed during the event studied. The CoM height, $z_{\mathrm{c}}$, for each layer is calculated based on the definition given by Mona et al. (2006) and Mona et al. (2012b). More specifically, the height of the CoM is estimated by the calculation of the backscatter weighted altitude $\left(z_{\mathrm{c}}\right)$ given as follows:

$$
z_{\mathrm{c}}=\frac{\int_{\text {bot }}^{z_{\text {top }}} z \times b_{\mathrm{aer}} \mathrm{d} z}{\int_{z_{\text {bot }}}^{z_{\text {top }}} b_{\text {aer }} \mathrm{d} z} .
$$

The weighted, in terms of height, value of CoM is a good approximation of the true aerosol CoM in the case where both aerosol composition and size distribution are constant with height. Under such conditions, this approach provides the valuable information of the altitude where the majority of the particles is located (Mona et al., 2006). In Fig. 3 (left panel) we present the temporal evolution of the CoM height of the volcanic aerosol layers for the period from 21 (12:00 UTC) to 23 April 2010 (00:00 UTC), using hourly averaged lidar data. The colored circles correspond to the $b_{\text {aer }}$ at $532 \mathrm{~nm}$. In order to calculate $b_{\text {aer }}$ we apply the well-known Klett technique (Klett, 1985) using a $S$ value of $60 \mathrm{sr}$, which is in agreement with our measurements for this event.

We have to note here that for the calculation of the CoM values, we took into account even the lowest and measured $b_{\text {aer }}$ values on the order of $1.5 \times 10^{-8} \mathrm{~m}^{-1} \mathrm{sr}^{-1}$. Figure 3 (left panel), two clusters can be clearly seen for aerosol particles detected in the upper troposphere (3-9 km a.s.l.) and in the lower troposphere $(<3 \mathrm{~km}$ a.s.1.). According to FLEXPART simulations presented earlier, the upper tropospheric particles (and as will be shown later, they are mostly composed of coarse particles with $r_{\text {eff }}$ around $0.37 \mu \mathrm{m}$ ) traveled 

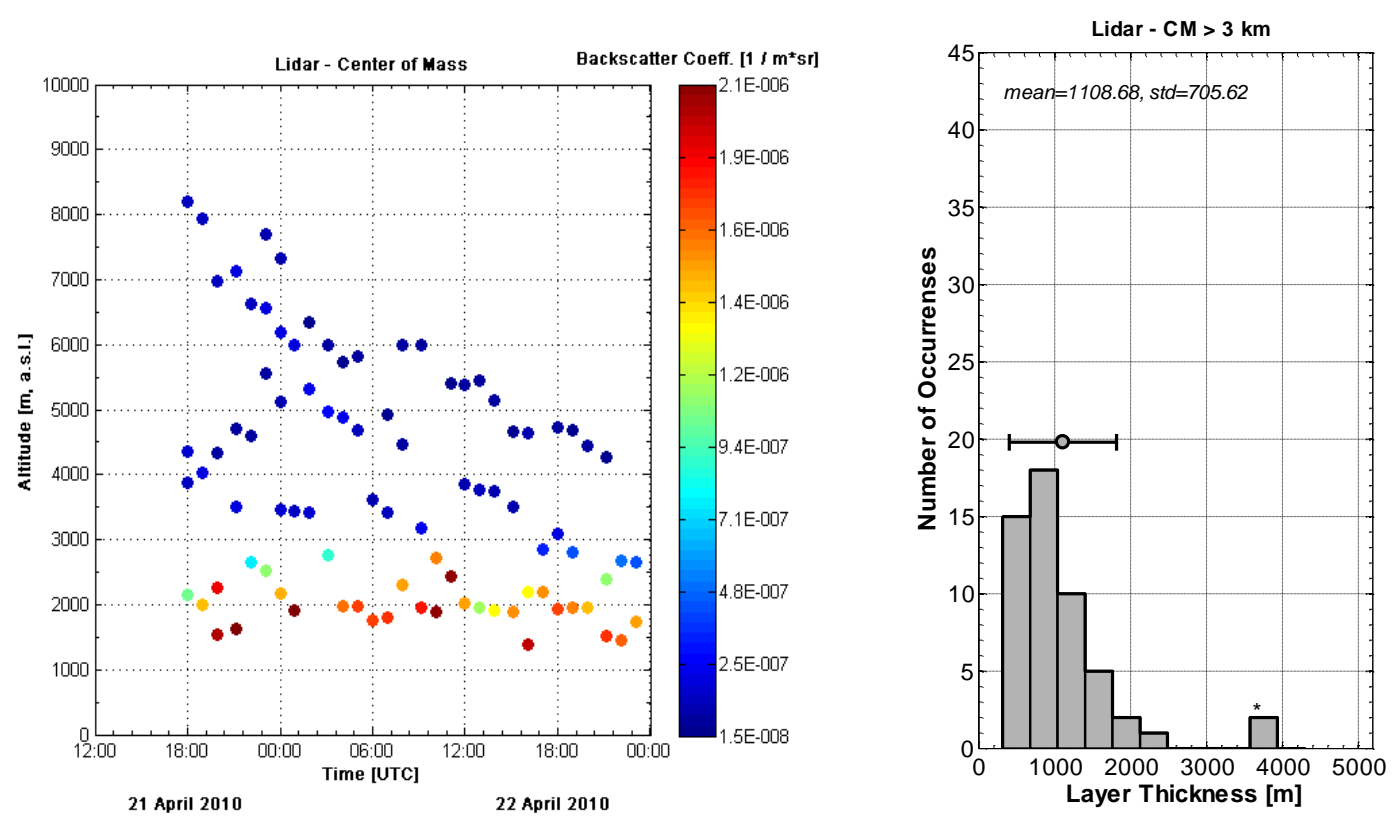

Fig. 3. Left panel: center of mass (CoM) of the volcanic ash layers, as detected by Raman lidar measurements over Athens (hourly averaged data) according to the aerosol backscatter coefficient (in $\mathrm{m}^{-1} \mathrm{sr}^{-1}$ ) at $532 \mathrm{~nm}$ for the period 21 April 2010 (12:00 UTC) and 23 April 2010 (00:00 UTC). Right panel: volcanic aerosol layer thickness distribution (in $\mathrm{m}$ ) according to Raman lidar measurements for a center of mass $(\mathrm{CoM})>3 \mathrm{~km}$ height for the period 21 April 2010 (12:00 UTC) and 23 April 2010 (00:00 UTC) over Athens. The dot corresponds to the position of the mean value of the aerosol layer thickness, while the error bar corresponds to the standard deviation of the distribution.

over central Europe and descended over our area. The lower tropospheric loads consist of smaller particles (as it will be shown later, $r_{\text {eff }}$ is on the order of $0.13 \mu \mathrm{m}$ ).

The same pattern of upper and lower tropospheric ash particles was simulated by FLEXPART as shown in Fig. 2 (upper panel). Specifically, if we calculate the CoM for FLEXPART as well using the concentration profiles instead of backscatter, the positions between the model and the lidar retrievals are highly correlated (Pearson's $r$ coefficient is on the order of 0.89). This fact indicates that a large portion of the PBL load for the dates under study consists of volcanic ash along with the locally emitted aerosols. However, it is difficult to distinguish the ash particles in the PBL, and thus we restrict our analysis only for the free-tropospheric ash load with $\mathrm{CoM}>3 \mathrm{~km}$, which is considered as pure ash. This is supported also by FLEXPART, which was found to be in better agreement with the lidar data for the higher aerosol layers $(\mathrm{CoM}>3 \mathrm{~km})$ than the lower ones $(\mathrm{CoM}<3 \mathrm{~km})$, showing a correlation coefficient for $\mathrm{CoM}>3 \mathrm{~km}$ that was $32.8 \%$ higher than for CoM $<3 \mathrm{~km}$.

For the layers with CoM greater than $3 \mathrm{~km}$, we present in Fig. 3 (right panel) an additional geometric property regarding the thickness of the layers observed. Specifically, the number of occurrences of the ash layer thickness as observed by lidar for $\mathrm{CoM}>3 \mathrm{~km}$ is presented. The dot corresponds to the position of the mean value of the aerosol layer thickness, while the error bar corresponds to the standard deviation. For the entire lidar observations, the mean value of the free-tropospheric ash layer thickness was found to be $1.1 \pm 0.7 \mathrm{~km}$. Based on the lidar observations, we found 25 cases with aerosol layer thickness between 0.8 and $1.2 \mathrm{~km}$, and 19 cases with aerosol layer thickness between 0.5 and $0.8 \mathrm{~km}$, which is quantitatively supported by FLEXPART as well.

\subsection{Ash concentrations}

In this section we apply the LIRIC code (Tsekeri et al., 2013; Wagner et al., 2013) to retrieve ash concentrations from the lidar-derived optical properties. The methodology followed is first demonstrated with an example, using as input to LIRIC an hourly mean aerosol profile obtained by lidar (from 03:00 to 04:00 UTC). LIRIC delivers also the backscatter profiles using a combination of sunphotometer and lidar data, which can then be compared with backscatter distributions found by the Klett technique as a measure of a successful run of the LIRIC algorithm. The comparison for our case is shown in Fig. 4 , where we compare the retrieved $b_{\text {aer }}$ profiles retrieved from the lidar measurements directly at 355 , 532 and $1064 \mathrm{~nm}$ (assuming typical mean $S$ values of $75 \mathrm{sr}$ at $355 \mathrm{~nm}, 65 \mathrm{sr}$ at $532 \mathrm{~nm}$ and $60 \mathrm{sr}$ at $1064 \mathrm{~nm}$, as obtained from the previous night's Raman lidar measurements) with the LIRIC $b_{\text {aer }}$ profiles retrieved at 355, 532 and $1064 \mathrm{~nm}$.

The LIRIC aerosol backscatter coefficient is calculated as the sum of the column-averaged fine and coarse particle backscatter coefficients from AERONET data, multiplied 


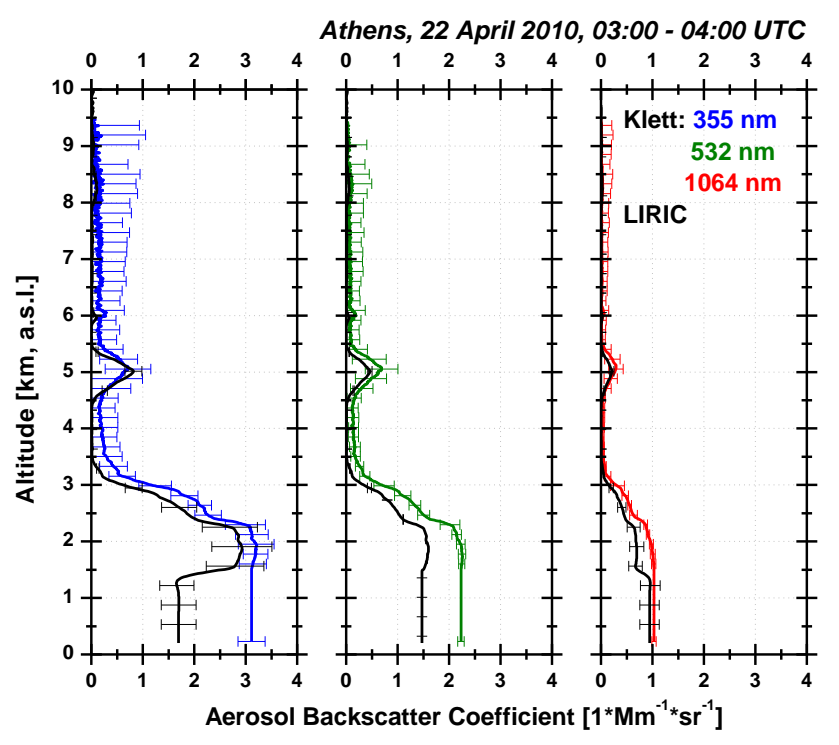

Fig. 4. Aerosol backscatter coefficient profiles (in $\mathrm{Mm}^{-1} \mathrm{sr}^{-1}$ ) calculated with two different methods, LIRIC (black line) and the Klett technique, at 355 (blue line), 532 (green line) and $1064 \mathrm{~nm}$ (red line), on 22 April 2010 (03:00-04:00 UTC) over Athens.

by the corresponding retrieved fine and coarse particle concentrations, as in Eq. (2). The comparison shows a quite good overall agreement, and thus the LIRIC run is most likely successful. The observed differences, which are mostly due to the constant $S$ values assumed and used as input in the Klett technique, remain in general within the error bar limits, except at the lower $1.2-2 \mathrm{~km}$ heights inside the PBL (only at 355 and $532 \mathrm{~nm}$ ), where they are on the order of $40-50 \%$. In order to determine the second term $\left(C_{\mathrm{f} / \mathrm{c}}(z)\right)$ of Eq. (1), we used the early morning AERONET observations (around 05:00 UTC), which is closest in time to the lidar one, minimizing errors due to the aerosol variability in the LIRIC version. In Fig. 5 we present the vertical profiles of the aerosol coarse and fine modes, as well as the total (fine and coarse mode) aerosol concentrations retrieved by LIRIC, and we add the FLEXPART total (fine and coarse) concentration profile simulation for comparison.

We can see that, in general, the position of the volcanic ash layers are well predicted by FLEXPART compared to LIRIC for altitudes greater than $2 \mathrm{~km}$, except for a relative vertical shift of about $0.5 \mathrm{~km}$ occurring between 2 and $4.5 \mathrm{~km}$ height. From the comparison it is clear that total concentrations are consistent for altitudes greater than $3 \mathrm{~km}$, so this is the tropospheric region where pure ash properties can be reported. The aforementioned analysis is applied in more lidar data for three consecutive and cloud-free synchronous lidarAERONET data sets obtained at 03:00, 06:00 and 07:00 UTC on 22 April, and the results are summarized in Fig. 6. In this figure we can see that for heights greater than $1.6 \mathrm{~km}$, the mean aerosol concentration, retrieved by LIRIC for all three data sets, was found to be $11 \pm 4 \mu \mathrm{g} \mathrm{m}^{-3}$, while it

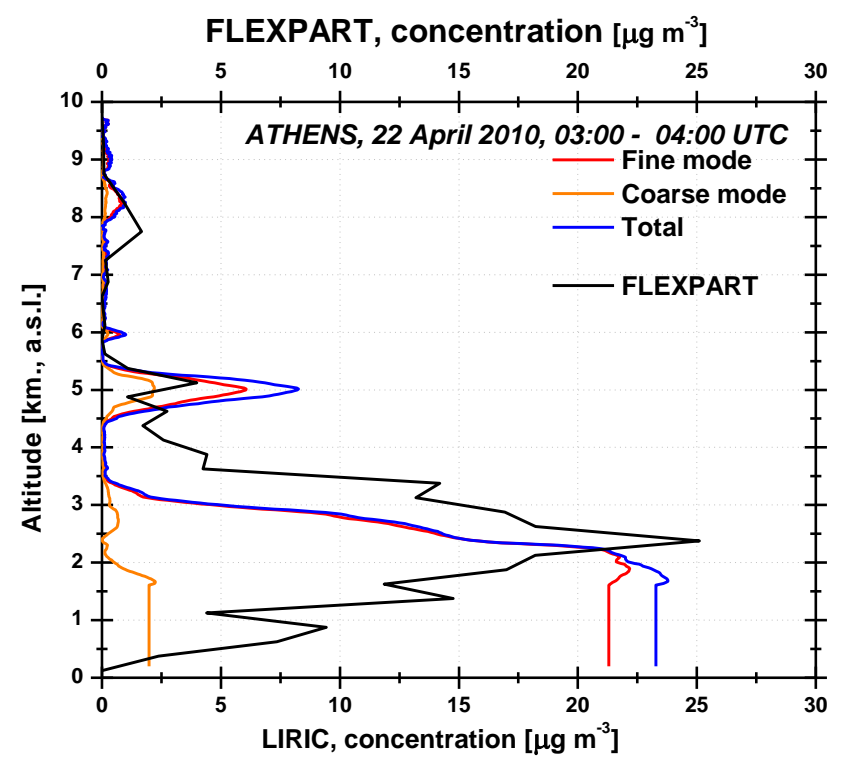

Fig. 5. Coarse mode, fine mode and total concentrations retrieved by LIRIC versus ash concentration (in $\mu \mathrm{g} \mathrm{m}^{-3}$ ) simulated by FLEXPART for 22 April 2010 (03:00 UTC) over Athens.

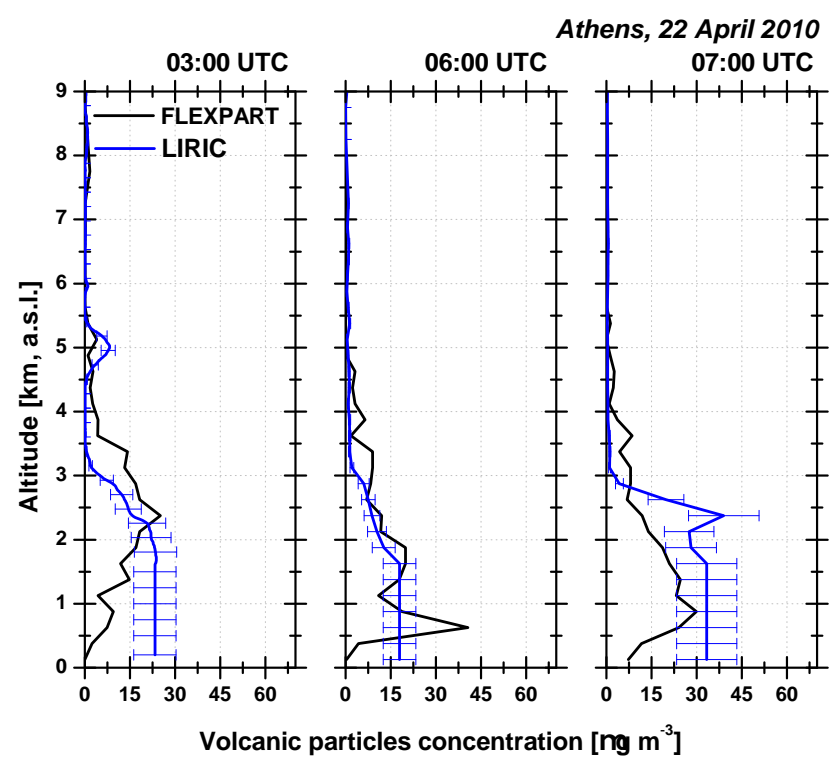

Fig. 6. Comparison of volcanic aerosol concentrations (in $\mu \mathrm{g} \mathrm{m}^{-3}$ ) retrieved by LIRIC and simulated by FLEXPART on 22 April 2010 over Athens at 03:00 (left), 06:00 (middle) and 07:00 UTC (right).

peaked up to $52 \mu \mathrm{g} \mathrm{m}^{-3}$ around $2.1 \mathrm{~km}$ at 03:00 UTC; the simulated concentrations by FLEXPART gave a mean value of $8.8 \pm 0.7 \mu \mathrm{g} \mathrm{m}^{-3}$ with a peak value around $25.1 \mu \mathrm{g} \mathrm{m}^{-3}$ around $2.4 \mathrm{~km}$ at 03:00 UTC.

The coefficient $R^{2}$ between the FLEXPART and LIRIC profiles ranged from 0.69 (at 03:00 UTC) to 0.84 (at 06:00 UTC), while it remained lower (0.74) at 07:00 UTC. Once again the comparison shows that there is quite good 


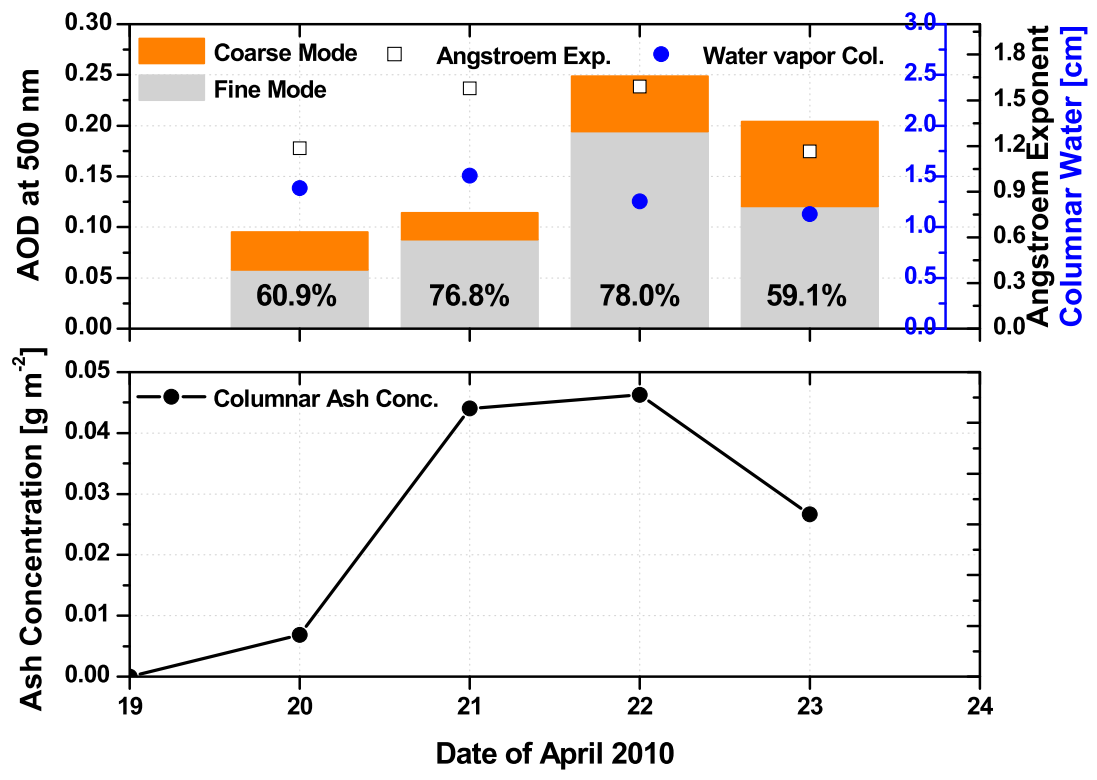

Fig. 7. AERONET fine/coarse-mode aerosol optical depth (AOD) obtained over Athens at $500 \mathrm{~nm}$ for the period between 19 and 24 April 2010, and Ångström exponent of $440 \mathrm{~nm} / 870 \mathrm{~nm}$ along with the columnar water vapor (in $\mathrm{cm}$ ) (upper graph). Temporal evolution of the volcanic ash columnar concentration (in $\mathrm{g} \mathrm{m}^{-2}$ ) according to FLEXPART simulations (lower graph).

agreement between FLEXPART and LIRIC for altitudes greater than $3 \mathrm{~km}$, indicating pure ash presence for these heights. Below this height, we observed a large discrepancy between these two methods at 03:00 UTC (around 120\%), and much less at 07:00 UTC (around 50\%). This is due to the fact that FLEXPART simulates only ash particles and LIRIC uses as input lidar signals from all kinds of mixed particles (volcanic and locally produced ones in the PBL of Athens).

\subsection{Volcanic aerosol characteristics and comparison with other studies}

In this section, we present the optical characteristics of volcanic aerosols as these were measured by AERONET and EARLINET stations over Athens, as well as microphysical properties retrieved by the lidar inversion algorithm. Firstly, column-integrated properties are presented in Fig. 7 (upper panel) in terms of the AERONET level 2.0 product for Athens for the period between 20 and 24 April. As we have already revealed from our analysis, columnar measurements do not refer to pure ash since the contamination of the column from local emissions maximizes within the PBL. However, from the temporal variation presented in the upper panel of Fig. 7, it is clear that before the arrival of ash particles over Athens, low AOD values at $500 \mathrm{~nm}(\sim 0.1)$ were recorded on 20 April, while during the advection on 21 and 22 April, the AOD values peaked at a value of 0.25 , which is very close to the value reported for April 2010 over Lille (France) by Derimian et al. (2012) and for May 2010 over Athens by Papayannis et al. (2012).
Once the event faded out, the AOD values decreased again to 0.20 . The respective fine-mode particles inside the atmospheric column were on the order of $59.1-60.9 \%$ before and after the event, and remained around 76.8-78.0\% during the event. This means that the fine-mode particles dominated. Such results were reported recently for ash particles over the Iberian Peninsula, as presented by Navas-Guzmán et al. (2013), but during the period of May 2010.

The fine-mode domination is supported also by the values if the AE retrieved from AODs at 440 and $870 \mathrm{~nm}$, found to be on the order of 1.2 before and during the fading phase of the event and on the order of 1.6 during the event, showing again the presence of rather small particles. This result is in contrast to values measured over central Europe (Ansmann et al., 2010), where AE values were on the order of 0.35-0.40 during the volcanic eruption event. However, the findings of Navas-Guzmán et al. (2013) and Papayannis et al. (2012) show $\mathrm{AE}$ values ranging between 1 and 1.6, which are very close to the ones presented here for long-range advection of ash. This long-range advection most probably allowed for the transportation of fine-mode particles only, with in general low concentrations over Greece. For example, FLEXPART's ash column loadings over central Europe a few days earlier forecasted values on the order of $600-1000 \mathrm{mg} \mathrm{m}^{-2}$ (Stohl et al., 2011), while in Greece, the maximum simulated ash loadings were $40-45 \mathrm{mg} \mathrm{m}^{-2}$ on 21 and 22 April (see also Fig. 1).

Moreover, the volcanic particles presence had a moderate signature on sunphotometric data over Athens between 21 and 23 April since the coarse-mode AOD (as an absolute 


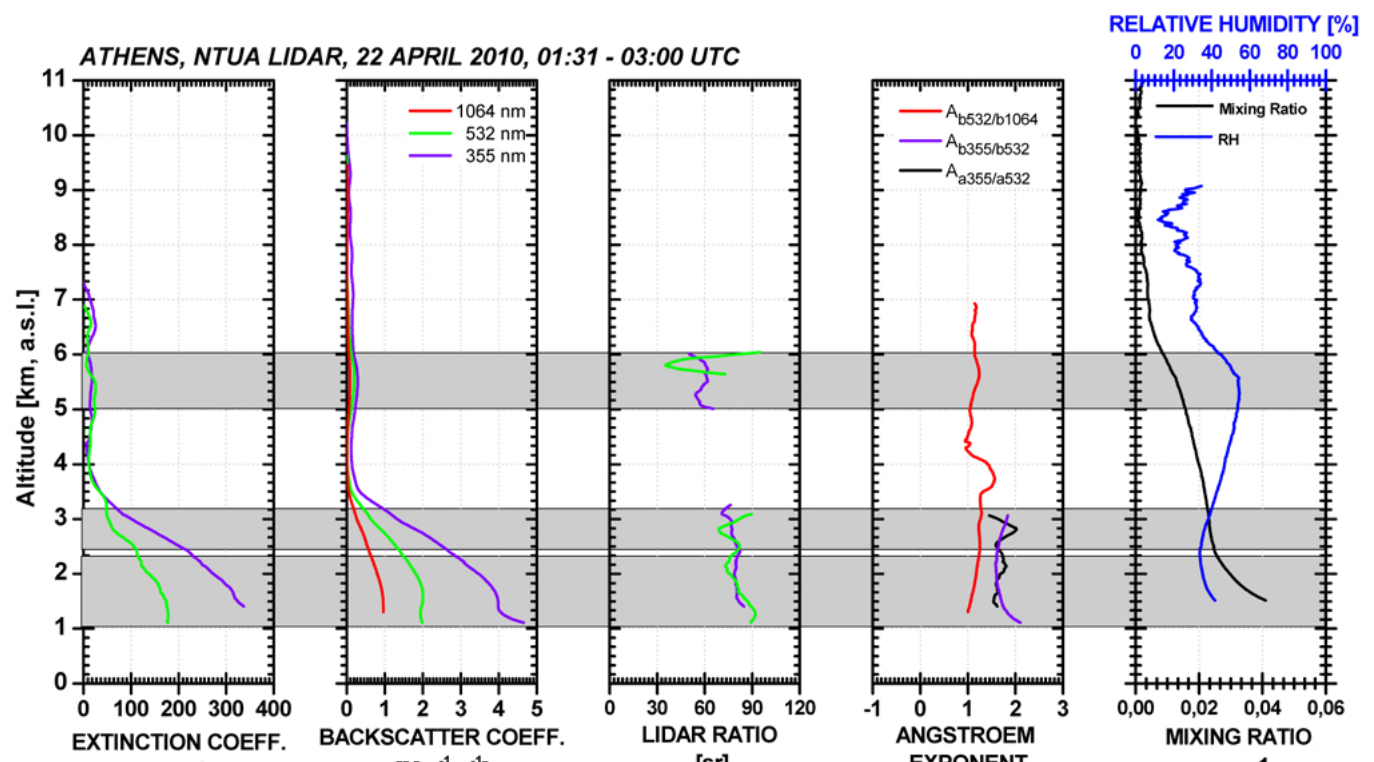

$\left[\mathrm{Mm}^{-1}\right] \quad\left[\mathrm{Mm}^{-1} \mathrm{sr}^{-1}\right] \quad$ EXPONENT $\quad\left[\mathrm{g} \mathrm{kg}^{-1}\right]$

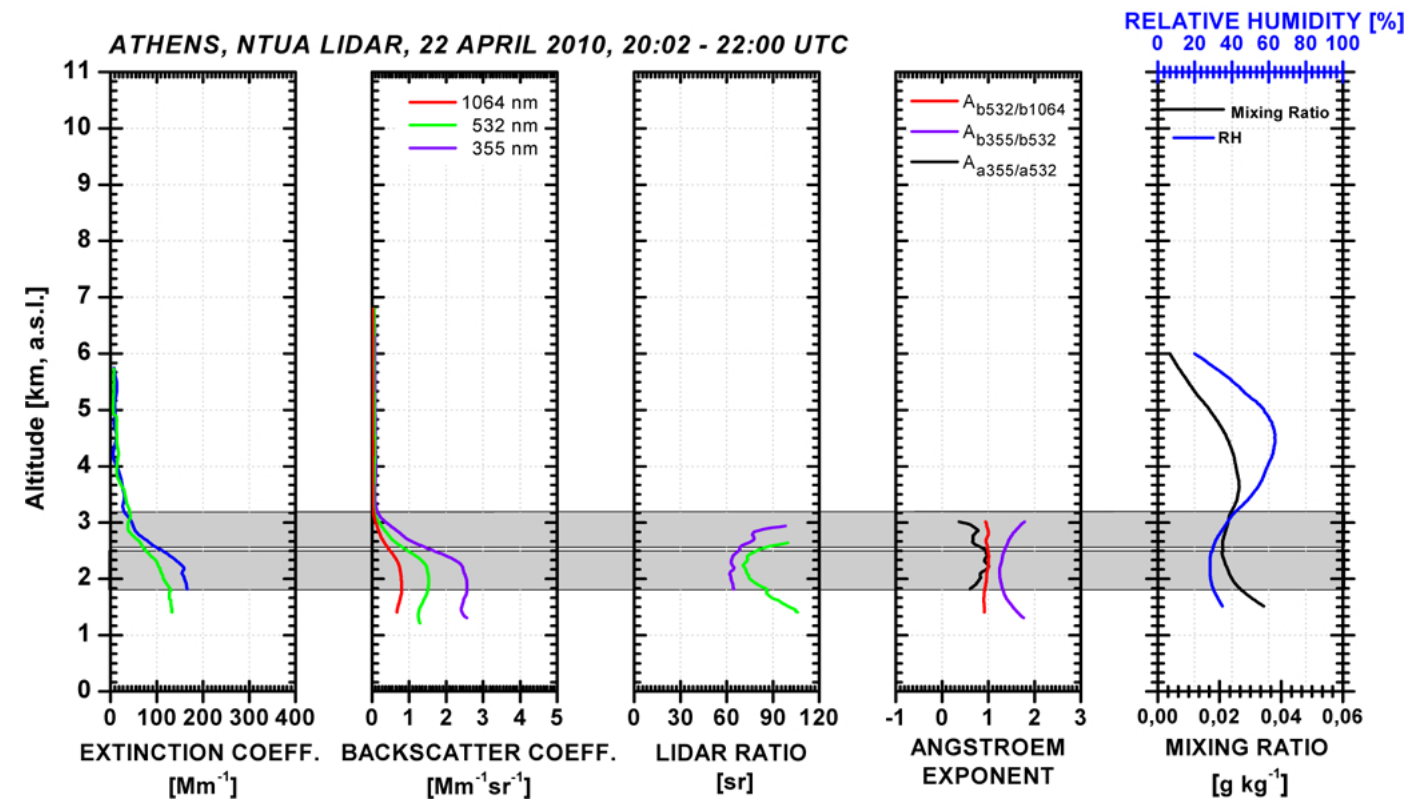

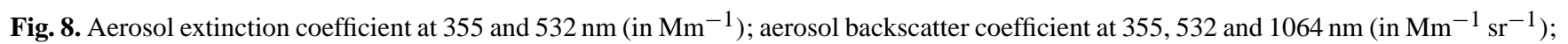
lidar ratio $(S)$ at 355 and $532 \mathrm{~nm}$ (in sr); aerosol extinction and backscatter-related Ångström exponent (355 nm/532 nm); water vapor mixing ratio (in $\mathrm{g} \mathrm{kg}^{-1}$ ); and relative humidity [\%], as retrieved by Raman lidar measurements over Athens on 22 April 2010 between 01:30 and 03:00 UTC (upper graph) and 20:00 and 22:00 UTC (lower graph).

value) increased by about $20 \%$ during the event (Fig. 7 , upper panel). The ash concentration as this is simulated by FLEXPART is presented in the lower panel of Fig. 7 to denote the volcanic advection.

In order to further characterize the volcanic particles over Athens, in terms of optical properties, we analyzed our cloud-free Raman lidar measurements (based on the retrieval of two $a_{\text {aer }}$ (at 355 and $532 \mathrm{~nm}$ ) and three $b_{\text {aer }}$ (at 355,532 and $1064 \mathrm{~nm}$ ) profiles) for two time windows on 22 April (depicted also by the aerosol masking in Fig. 2, lower panel):
01:30-03:00 UTC and 20:02-22:00 UTC. Firstly, we calculated the vertical profiles (Fig. 8) of the aerosol optical properties, such as the $\alpha_{\text {aer }}, b_{\text {aer }}, S$, EAE and BAE values at 355 , 532 and $1064 \mathrm{~nm}$, based on our Raman lidar data on 22 April between 01:30 and 03:00 UTC (upper graph) and between 20:02 and 22:00 UTC (lower graph).

More precisely (Fig. 8, upper graph), based on the $\alpha_{\text {aer }}$ and $b_{\text {aer }}$ vertical profiles, the aerosol masking and the FLEXPART simulations, the aerosol layers between 1 and $2.3 \mathrm{~km}$, 2.5 and $3 \mathrm{~km}$ and 5 and $6 \mathrm{~km}$ are considered to be volcanic 
Table 1. Mean values and standard deviations of the aerosol extinction-related Ångström exponent ( $355 \mathrm{~nm} / 532 \mathrm{~nm})$, aerosol backscatterrelated Ångström exponent $(355 \mathrm{~nm} / 532 \mathrm{~nm}$ and $532 \mathrm{~nm} / 1064 \mathrm{~nm}$ ), lidar ratio (at 355 and $532 \mathrm{~nm}$ ) and aerosol optical depth at 355 and $532 \mathrm{~nm}$ obtained by the Raman lidar over Athens, Greece, between 01:30 and 03:00 UTC (upper part) and 20:00 and 22:00 UTC (lower part).

\begin{tabular}{|c|c|c|c|c|c|c|c|c|}
\hline & \multicolumn{8}{|c|}{ ATHENS, NTUA LIDAR, 22 APRIL 2010, 01:30-03:00 UTC } \\
\hline & Height $[\mathrm{m}]$ & $\mathrm{Aa}(355 / 532)$ & $\mathrm{Ab}(355 / 532)$ & $\mathrm{Ab}(532 / 1064)$ & S355 & S532 & AOD355 & AOD532 \\
\hline LAYER 1 & $1000-2300$ & $1.69 \pm 0.07$ & $1.61 \pm 0.02$ & $1.17 \pm 0.03$ & $80 \pm 1$ & $77 \pm 3$ & 0.18 & 0.17 \\
\hline LAYER 2 & $2500-3000$ & $1.79 \pm 0.15$ & $1.72 \pm 0.06$ & $1.24 \pm 0.01$ & $78 \pm 1$ & $76 \pm 5$ & 0.08 & 0.04 \\
\hline \multirow[t]{3}{*}{ LAYER 3} & $5000-6000$ & $0.66 \pm 0.06$ & $-0.3 \pm 0.05$ & $1.19 \pm 0.04$ & $60 \pm 2$ & $44 \pm 8$ & 0.01 & 0.02 \\
\hline & \multicolumn{8}{|c|}{ ATHENS, NTUA LIDAR, 22 APRIL 2010, 20:00-22:00 UTC } \\
\hline & Height $[\mathrm{m}]$ & $\mathrm{Aa}(355 / 532)$ & $\mathrm{Ab}(355 / 532)$ & $\mathrm{Ab}(532 / 1064)$ & S355 & S532 & AOD355 & AOD532 \\
\hline LAYER 1 & $2000-2400$ & $0.91 \pm 0.06$ & $1.26 \pm 0.02$ & $0.98 \pm 0.02$ & $63 \pm 1$ & $73 \pm 1$ & 0.09 & 0.06 \\
\hline LAYER 2 & $2500-3000$ & $0.71 \pm 0.12$ & $1.52 \pm 0.12$ & $0.97 \pm 0.01$ & $77 \pm 7$ & $88 \pm 7$ & 0.04 & 0.03 \\
\hline
\end{tabular}

particles layers (denoted by gray stripes). Similarly, in Fig. 8 (lower graph) the aerosol layers from 1.8 to $3.2 \mathrm{~km}$ are considered to be volcanic particles layers.

By comparing the nighttime Raman measurements of 22 April (Fig. 8), we can see that the EAE values decreased from 1.75 (during the period 01:30-03:00 UTC) (Fig. 8, upper graph) to 0.81 (20:02-22:00 UTC) (Fig. 8, lower graph), leaving the coarser particles in the lower parts of the atmosphere (between 2 and $3 \mathrm{~km}$ ). Additionally, between the two layers extending from 2 to $2.4 \mathrm{~km}$ and 2.5 to $3 \mathrm{~km}$ (20:0222:00 UTC), a shift in the optical properties is observed. The $S$ values increased from 63 to $77 \mathrm{sr}$ at $355 \mathrm{~nm}$ and from 73 to $88 \mathrm{sr}$ at $532 \mathrm{~nm}$.

In addition, the EAE values decreased from 0.91 to 0.71 . This variability in combination with the increasing value of the relative humidity (from 20 to $40 \%$ ) is leading to a scenario in which the volcanic particles, which are coated with sulfate, were coagulated with water vapor (Lathem et al., 2011) during their transport and/or mixed with locally produced particles, resulting in bigger particles. This same pattern of increasing $S$ values with increasing relative humidity is also reported by Mona et al. (2012a).

In Table 1 we present the mean optical properties of the volcanic particles calculated within the identified aerosol layers for these two time windows: EAE (pair 355-532 nm), BAE (pairs 355-532 nm, 532-1064 nm), $S$ (at 355 and $532 \mathrm{~nm}$ ) and AOD (at 355 and $532 \mathrm{~nm}$ ) values. We see that the EAE values ranged between 0.66 and 1.79, the BAE values (532-1064 $\mathrm{nm}$ pair) ranged between 0.97 and 1.24, and the BAE values (355-532 nm pair) ranged mainly between 1.26 and 1.72. The $S$ values inside the volcanic plume at $355 \mathrm{~nm}$ ranged between 60 and $80 \mathrm{sr}$, while at $532 \mathrm{~nm}$ they ranged between 44 and $88 \mathrm{sr}$. These values are very similar to those reported for Germany (Gross et al., 2012, on 17 April at Maisach; Ansmann et al., 2010, in Leipzig) and for Italy (Mona et al., 2012a, on 19-22 April in Potenza), as we will discuss later. Our findings for May 2010 (Papayannis et al., 2012) showed very similar values for $S$ inside the volcanic layers.

Additionally, based on the $\alpha_{\text {aer }}$ values measured by our lidar system inside the almost pure volcanic layer (between 5 and $6 \mathrm{~km}$ on 22 April from 01:30 to 03:00 UTC), the corresponding AOD values at $355 \mathrm{~nm}$ and $532 \mathrm{~nm}$ were 0.01 and 0.02 , respectively, which are similar to those reported by Sicard et al. (2012) over the Iberian peninsula, but considerably lower than from those measured over Athens one month later (Papayannis et al., 2012).

In the following we compare (cf. Fig. 9) the main volcanic aerosol optical properties, as measured by three EARLINET stations from 17 to 23 April over Maisach, Germany (Gross et al., 2011); Potenza, Italy (Mona et al., 2012a); and Athens, Greece (present study). We can see in this figure that, over Maisach, inside the volcanic particles layers, the mean particle depolarization ratio (denoted by open dots) was found to be nearly wavelength independent: 0.35 (at $355 \mathrm{~nm}$ ) and 0.36 (at $532 \mathrm{~nm}$ ). The $S$ values were found to be $55 \pm 5 \mathrm{sr}$ (at $355 \mathrm{~nm}$ ) and $50 \pm 5 \mathrm{sr}$ (at $532 \mathrm{~nm}$ ). Three days later (on 20 April), the observations performed in Italy by Mona et al. (2012a) showed that the $S$ values at $355 \mathrm{~nm}$ inside the volcanic particles layer had remained of the same order ( $\sim 54 \pm 13 \mathrm{sr}$ ), while on the following day (on 21 April) they strongly decreased to around $40 \pm 5 \mathrm{sr}$ compared to the ones measured over Maisach; additionally, the $S$ value at $532 \mathrm{~nm}$ over Italy was of the same order as over Maisach.

However, the mean particle depolarization ratio at $532 \mathrm{~nm}$ dropped to lower values $(0.15-0.23)$ compared to the ones measured over Maisach $(0.35-0.36)$. Later, at the end of 22 April, the mean particle depolarization values increased back to 0.25 (at $532 \mathrm{~nm}$ ), as the $S$ values were 78 and $80 \mathrm{sr}$ (at 532 and $355 \mathrm{~nm}$, respectively). Finally, over Athens on the 22 April (01:30-03:00 UTC), the $S$ values were 75-80 sr (between 1 and $3 \mathrm{~km}$ ) and around $60 \mathrm{sr}$ (between 5 and $6 \mathrm{~km}$ ). Later on that day (20:00-22:00 UTC), the $S$ values inside the 


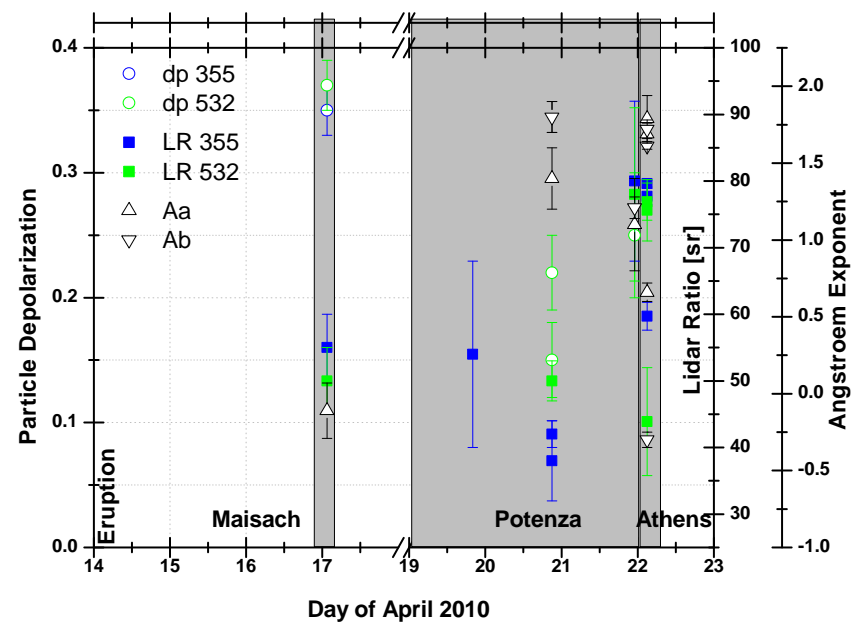

Fig. 9. Aerosol optical properties (depolarization ratio, $S$, extinction and backscatter-related Ångström exponent) from various studies of the inside of volcanic aerosol layers, as obtained over Maisach, Germany (Gross et al., 2011); Potenza, Italy (Mona et al., 2012a); and Athens, Greece (present study), from 17 to 23 April 2010.

volcanic plume at $355 \mathrm{~nm}$ ranged between 60 and $80 \mathrm{sr}$, while at $532 \mathrm{~nm}$ they ranged between 44 and $88 \mathrm{sr}$.

Generally, it seems that the optical properties of the volcanic aerosols were modified during their transport from the source region to our site, showing a decreasing trend in particle depolarization ratio in combination with an increasing trend in the EAE and BAE values. This scenario shows that the volcanic plume was at first mostly composed of highly nonspherical coarse particles, which during their advection to Athens (aging) either were removed by dry and/or wet deposition or mixed with other particles (haze or urban), leading to more spherical and smaller particles. This is corroborated by an air mass back-trajectory analysis based on the FLEXPART model (see also Fig. 1) indicating that the aerosol-rich air masses sampled between 1.5 and $3 \mathrm{~km}$ height had stagnated over central Europe four days before our observations, where they were enriched with polluted and small anthropogenic particles of industrial and urban origin.

The aforementioned assumption is further supported by the aerosol columnar sphericity (Dubovik et al., 2006) values obtained from three different AERONET stations in Europe (Leipzig, Potenza and Athens), presented in Fig. 10. Two days after the volcanic eruption onset, from 16 up to 19 April, the majority of the columnar sphericity values over Leipzig (denoted by black crosses) were below $35 \%$ (although in some cases nearly spherical particles existed as well, with sphericities between 60 and $99 \%$ ), indicating that the atmosphere over Germany was dominated mostly by nonspherical particles. Over Potenza on 21 April (denoted by blue circles) the majority of the columnar sphericity values showed increased values of up to $58 \%$ for Italy, while over Athens (denoted by triangles) most of the particles became even more

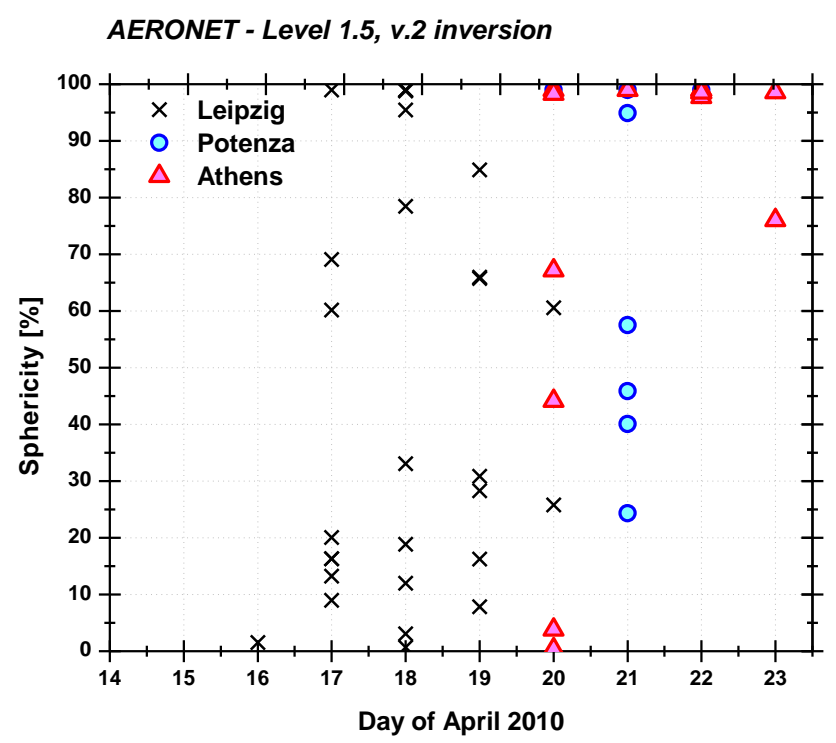

Fig. 10. Columnar aerosol sphericity values obtained from the AERONET level 1.5 standard product over Leipzig, Potenza and Athens from 16 to 23 April 2010.

spherical, with sphericity values on the order of 75-99\%. As discussed before, the increasing sphericity of the volcanic aerosols is probably linked to mixing with locally produced anthropogenic particles.

In Fig. 11 we present the main aerosol microphysical properties $\left(r_{\text {eff }}, m_{\mathrm{R}}, m_{\mathrm{I}}\right)$ together with the $\mathrm{NC}$ values, as retrieved from lidar signal inversion techniques (see Sect. 2.5) for the five aerosol layers shown in Table 1. More precisely, during the early hours of 22 April (01:30-03:00 UTC), we see that in the two layers below $3 \mathrm{~km}$ height, we had the presence of rather small particles with $r_{\text {eff }}$ below $0.13 \mu \mathrm{m}$, but in high concentrations ( $\mathrm{NC}>4000$ particles $\mathrm{cm}^{-3}$ ) (Fig. 11a, left graph). Moreover, these particles showed quite high absorption ( $m_{\mathrm{I}}$ values were on the order of $\left.0.006-0.010\right)$ with $m_{\mathrm{R}}$ values ranging between 1.38 and 1.39 (Fig. 11a, right graph). At higher altitudes (around $5.5 \mathrm{~km}$ height) $\mathrm{NC}$ dropped to very low values $\left(\mathrm{NC} \sim 20\right.$ particles $\left.\mathrm{cm}^{-3}\right)$, but their $r_{\text {eff }}$ values increased to around $0.38 \mu \mathrm{m}$. However, they showed quite low absorption ( $m_{\mathrm{I}}$ values were on the order of $0.006)$ and a mean $m_{\mathrm{R}}$ value of 1.49 .

During the nighttime, measurements of the same day (20:00-22:00 UTC) NC (Fig. 11b, left graph) decreased below $3 \mathrm{~km}$ height to less than 700 particles, but their mean effective radius increased to about $0.20-0.24 \mu \mathrm{m}$. However, they showed a lower absorption $\left(m_{\mathrm{I}}\right.$ values were on the order of 0.003 ), while the $m_{\mathrm{R}}$ values were 1.57 at $2.2 \mathrm{~km}$ and 1.47 at $2.8 \mathrm{~km}$ height (Fig. 11b, right graph). Our $r_{\text {eff }}$ values were much lower than those retrieved over Germany (Ansmann et al., 2010; Gasteiger et al., 2011; Weber et al., 2012) and France (Derimian et al., 2012), as these countries are much closer to the volcanic source region of Eyjafjallajökull than 


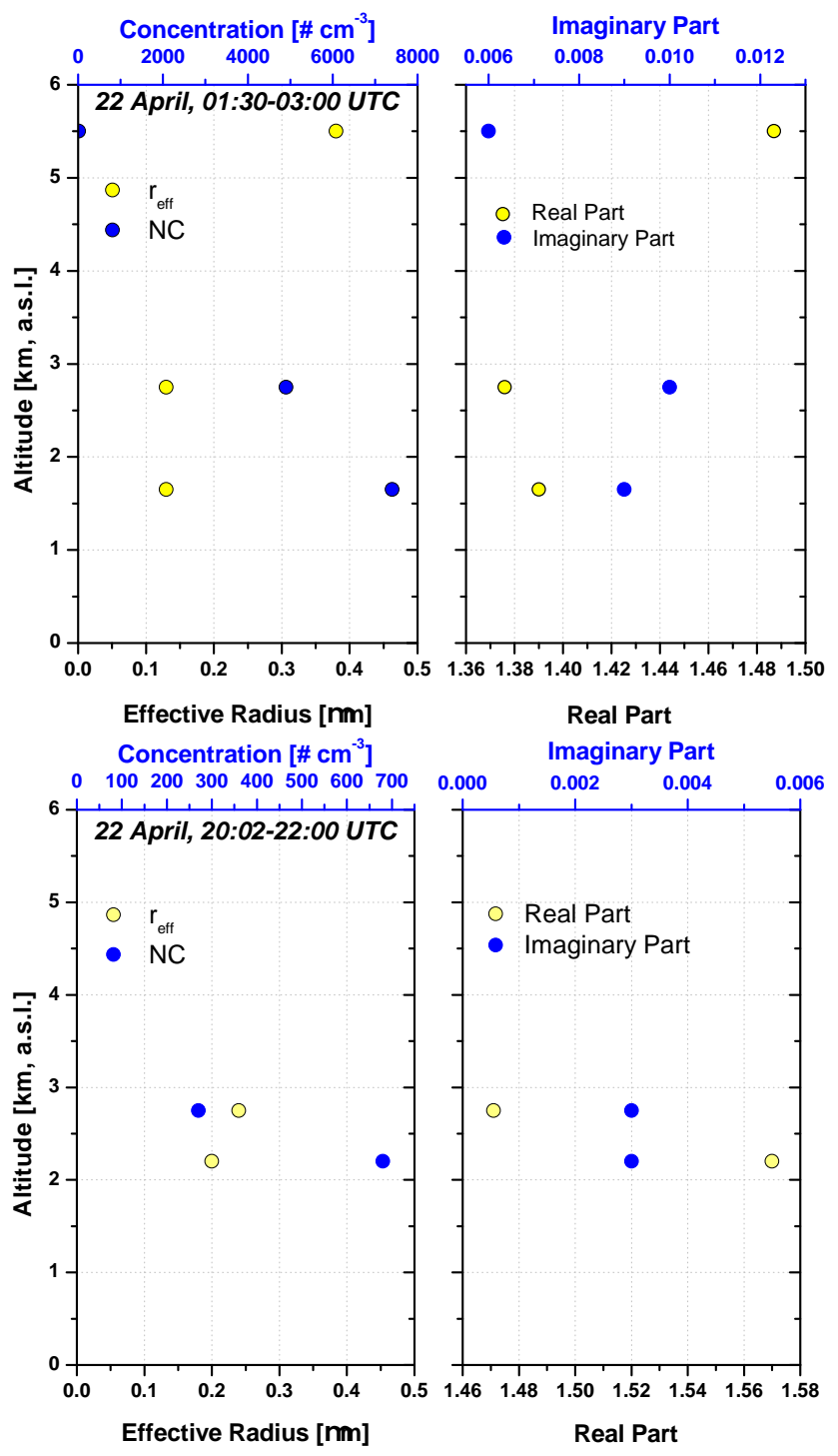

Fig. 11. Aerosol properties derived from lidar inversion code using NTUA Raman lidar data: mean effective radius, number concentration, and refractive index (real and imaginary part) between 0.6 and $6 \mathrm{~km}$ height over Athens on 22 April 2010. (a) Between 01:30 and 03:00 UTC and (b) between 20:00 and 22:00 UTC.

Greece and larger particles stay close to their source due to gravitational settling.

\section{Summary}

In this paper we presented the vertical profiles of the optical ( $a_{\text {aer }}$ and $b_{\text {aer }}, S$, EAE and BAE), microphysical (mean $r_{\text {eff }}$, mean $m_{\mathrm{R}}$ and $m_{\mathrm{I}}$, mean NC) and geometrical properties (layer thickness and aerosol center of mass) as well as the mass concentration of volcanic particles from the Eyjafjallajökull eruption, as retrieved for selected heights using a multi-wavelength Raman lidar system and inverse models, during the first days of the arrival of the volcanic particles over Athens, Greece, in the period of 21-24 April 2010. The days of 21 and 22 April were characterized by the maximum presence of volcanic particles over Athens, with high finemode fractions in the total AOD (76.8 and 78.0\%, respectively) and quite high $\mathrm{AE}$ values (on the order of 1.6) using collocated AERONET measurements (level 2.0 data) and aerosol masking schemes. Additionally, high columnar ash concentrations $\left(\sim 0.045 \mathrm{~g} \mathrm{~m}^{-2}\right)$ were simulated by FLEXPART. The highest maximum AOD value $(\sim 0.25$ at $500 \mathrm{~nm})$ was measured on 22 April, which was very similar to our volcanic particles observations on 12 May 2010 (Papayannis et al., 2012).

During the studied period, continuous lidar measurements were performed, revealing the presence of upper and lower midtropospheric volcanic aerosols. Lofted volcanic particles layers at about $10 \mathrm{~km}$ height showed a downward motion during late afternoon hours on 21 April, similar to observations reported for the same period by Mona et al. (2012a). On the early hours of the following day (01:30-03:00 UTC), three distinct volcanic particles layers (between 1 and $6 \mathrm{~km}$ height) were identified and characterized in terms of their optical, microphysical and geometrical properties. The mean AOD value inside the volcanic particles layers was rather low: 0.09 (ranging from 0.01 to 0.18 ) at $355 \mathrm{~nm}$ and 0.07 (ranging from 0.02 to 0.17 ) at $532 \mathrm{~nm}$. The corresponding values for $S$ ranged from 60 to $80 \mathrm{sr}$ (mean value $72 \mathrm{sr}$ ) at $355 \mathrm{~nm}$ and from 44 to $77 \mathrm{sr}$ (mean value $65 \mathrm{sr}$ ) at $532 \mathrm{~nm}$. For the second time window of 22 April (20:02-22:00 UTC), two distinct volcanic particles layers were identified (between 2 and $3 \mathrm{~km}$ height). The mean AOD value inside these layers was rather low: 0.06 (ranging from 0.04 to 0.09 ) at $355 \mathrm{~nm}$ and 0.05 (ranging from 0.03 to 0.06 ) at $532 \mathrm{~nm}$. The corresponding values for $S$ ranged from 63 to $77 \mathrm{sr}$ (mean value $70 \mathrm{sr}$ ) at $355 \mathrm{~nm}$ and from 73 to $88 \mathrm{sr}$ (mean value $81 \mathrm{sr}$ ) at $532 \mathrm{~nm}$. For the volcanic particles layers below $3 \mathrm{~km}$ height, the respective EAE value $(355 \mathrm{~nm} / 532 \mathrm{~nm})$ ranged from 0.66 to 1.79 .

The main differences from the measurements performed in May 2010 over Athens (Papayannis et al., 2012) are mostly focused on the higher heights where volcanic particles were observed in April (10 km on April versus $6 \mathrm{~km}$ on May), as well as that during April, volcanic particles were mixed with locally produced ones in the lower troposphere, while in May they were mixed with advected dust particles.

The retrieval of the volcanic particles microphysical properties showed that the size of the lofted aerosols increased with height, as the mean $r_{\text {eff }}$ value of the volcanic particles, for both time windows, ranged from 0.13 to $0.38 \mu \mathrm{m}$. The $m_{\mathrm{R}}$ value of the volcanic particles ranged from 1.37 to 1.57 , while $m_{\mathrm{I}}$ ranged from 0.003 to 0.006 , indicating slight absorption by these particles. In contrast to lidar observations in northern and central Europe that detected optically thick lofted nonspherical volcanic particles, most of the volcanic particles that reached Athens finally reached 
the lower troposphere, where they penetrated the PBL and became more spherical as it was mixed with locally produced anthropogenic aerosols. Finally, we compared, for the first time, the volcanic particle concentrations simulated by FLEXPART with those calculated by LIRIC for three-time coincident lidar-AERONET data sets. This comparison has proved to be quite successful mostly above the PBL height (between 2.5 and $5.5 \mathrm{~km}$ height), with $R^{2}$ values close to 0.75 .

Acknowledgements. The research of P. Kokkalis has been cofinanced by the European Union (European Social Fund - ESF) and Greek national funds through the Operational Program "Education and Lifelong Learning" of the National Strategic Reference Framework (NSRF) Research Funding Program: Heracleitus II - Investing in knowledge society through the European Social Fund. A. Papayannis, G. Tsaknakis, L. Mona, R. E. Mamouri and V. Amiridis acknowledge that the research leading to these results has received also funding from the European Union's Seventh Framework Programme (FP7/2007-2013) under grant agreement no. 262254 (ACTRIS). The authors would like to thank both reviewers for their helpful comments and suggestions.

Edited by: A. Nenes

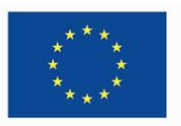

European Union European Social Fund

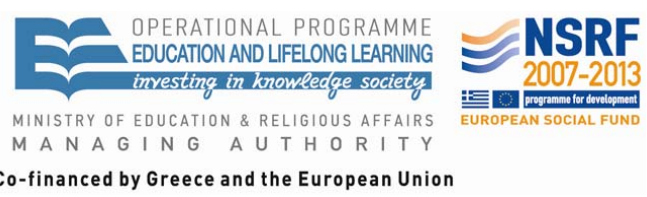

\section{References}

Ansmann A., Riebesell, M., Wandinger, U., Weitkamp, C., Voss, E., Lahmann, W., and Michaelis, W.: combined Raman elasticbackscatter lidar for vertical profiling of moisture, aerosol extinction, backscatter, and lidar ratio, Appl. Phys., B55, 18-28, 1992.

Ansmann, A., Tesche, M., Groß, S., Freudenthaler, V., Seifert, P., Hiebsch, A., Schmidt, J., Wandinger, U., Mattis, I., Müller, D., and Wiegner, M.: The 16 April 2010 major volcanic ash plume over central Europe: EARLINET lidar and AERONET photometer observations at Leipzig and Munich, Germany, Geophys. Res. Lett., 37, L13810, doi:10.1029/2010GL043809, 2010.

Ansmann, A., Tesche, M., Seifert, P., Groß, S., Freudenthaler, V., Apituley, A., Wilson, K. M., Serikov, I., Linné, H., Heinold, B., Hiebsch, A., Schnell, F., Schmidt, J., Mattis, I., Wandinger, U., and Wiegner, M.: Ash and fine mode particle mass profiles from EARLINET-AERONET observations over central Europe after the eruptions of the Eyjafjallajökull volcano in 2010, J. Geophys. Res., 116, D00U02, doi:10.1029/2010JD015567, 2011.

Ansmann, A., Seifert, P., Tesche, M., and Wandinger, U.: Profiling of fine and coarse particle mass: case studies of Saharan dust and Eyjafjallajökull/Grimsvötn volcanic plumes, Atmos. Chem. Phys., 12, 9399-9415, doi:10.5194/acp-12-9399-2012, 2012.

Böckmann, C., Wandinger, U., Ansmann, A., Bösenberg, J., Amiridis, V., Boselli, A., Delaval, A., De Tomasi, F., Frioud, M., Grigorov, I., Hagard, A., Horvat, M., Iarlori, M., Komguem, L.,
Kreipl, S., Larcheveque, G., Matthias, V., Papayannis, A., Pappalardo, G., Rocadenbosch, F., Rodrigues, J. A., Schneider, J., Shcherbakov, V., and Wiegner, M.: Aerosol lidar intercomparison in the framework of the EARLINET project: Part II - Aerosol backscatter algorithms, Appl. Optics, 43, 977-989, 2004.

Bösenberg, J., Timm, R., and Wulfmeyer, V.: Study of retrieval algorithms for a backscatter lidar, Final Report, MPI Report No. 226, 1-66 pp., Hamburg, 1997.

Bösenberg, J., Matthias, V., Amodeo, A., Amoiridis, V., Ansmann, A., Baldasano, J. M., Balin, I., Balis, D., Böckmann, C., Boselli, A., Carlsson, G., Chaikovsky, A., Chourdakis, G., Comeron, A., De Tomasi, F., Eixmann, R., Freudenthaler, V., Giehl, H., Grigorov, I., Hagard, A., Iarlori, M., Kirsche, A., Kolarov, G., Kolarev, L., Komguem, G., Kreipl, S., Kumpf, W., Larchevêque, G., Linné, H., Matthey, R., Mattis, I., Mekler, A., Mironova, I., Mitev, V., Mona, L., Müller, D., Music, S., Nickovic, S., Pandolfi, M., Papayannis, A., Pappalardo, G., Pelon, J., Pérez, C., Perrone, R. M., Persson, R., Resendes, D. P., Rizi, V., Rocadenbosch, F., Rodrigues, J. A., Sauvage, L., Schneidenbach, L., Schumacher, R., Shcherbakov, V., Simeonov, V., Sobolewski, P., Spinelli, N., Stachlewska, I., Stoyanov, D., Trickl, T., Tsaknakis, G., Vaughan, G., Wandinger, U., Wang, X., Wiegner, M., Zavrtanik, M., and Zerefos, C.: EARLINET: A European Aerosol Research Lidar Network., MPI-Report, Max-Planck-Institut für Meteorologie, Hamburg, Germany, 348, 1-191, 2003.

Bukowiecki, N., Zieger, P., Weingartner, E., Juranyi, Z., Gysel, M., Neininger, B., Schneider, B., Hueglin, C., Ulrich, A., Wichser, A., Henne, S., Brunner, D., Kaegi, R., Schwikowski, M., Tobler, L., Wienhold, F. G., Engel, I., Buchmann, B., Peter, T., and Baltensperger, U.: Groundbased and airborne in-situ measurements of the Eyjafjallajökull volcanic aerosol plume in Switzerland in spring 2010, Atmos. Chem. Phys., 11, 10011-10030, doi:10.5194/acp-11-10011-2011, 2011.

Carboni, E., Grainger, R., Walker, J., Dudhia, A., and Siddans, R.: A new scheme for sulphur dioxide retrieval from IASI measurements: application to the Eyjafjallajökull eruption of April and May 2010, Atmos. Chem. Phys., 12, 11417-11434, doi:10.5194/acp-12-11417-2012, 2012.

Chaikovsky, A., Bril, A., Barun, V., Dubovik, O., Holben, B., and Thompson, A.: Studying altitude profiles of atmospheric aerosol parameters by combined multi-wavelength lidar and sun sky radiance measurements. Reviewed and revised papers presented at the 22nd International Laser Radar Conference, Matera, Italy, 345-348, 2004.

Chaikovsky, A., Dubovik, O., Goloub, P., Tanré, D., Pappalardo, G., Wandinger, U., Chaikovskaya, L., Denisov, S., Grudo, Y., Lopatsin, A., Karol, Y., Lapyonok, T., Korol, M., Osipenko, F., Savitski, D., Slesar, A., Apituley, A., Arboledas, L. A., Binietoglou, I., Kokkalis, P., Granados Muñoz, M. J., Papayannis, A., Perrone, M. R., Pietruczuk, A., Pisani, G., Rocadenbosch, F., Sicard, M., De Tomasi, F., Wagner, J., and Wang, X.: Algorithm and software for the retrieval of vertical aerosol properties using combined lidar/radiometer data: Dissemination in EARLINET, Reviewed and revised papers presented at the 26th International Laser Radar Conference, Porto Heli, Greece, 399-402, 2012.

Chazette, P., Dabas, A., Sanak, J., Lardier, M., and Royer, P.: French airborne lidar measurements for Eyjafjallajökull ash plume survey, Atmos. Chem. Phys., 12, 7059-7072, doi:10.5194/acp-127059-2012, 2012. 
Dacre, H. F., Grant, A. L. M., Hogan, R. J., Belcher, S. E., Thomson, D. J., Devenish, B. J., Marenco, F., Hort, M. C., Haywood, J. M., Ansmann, A., Mattis, I., and Clarisse, L.: Evaluating the structure and magnitude of the ash plume during the initial phase of the 2010 Eyjafjallajökull eruption using lidar observations and NAME simulations, J. Geophys. Res., 116, D00U03, doi:10.1029/2011JD015608, 2011.

Derimian, Y., Dubovik, O., Tanré, D., Goloub, P., Lapyonok, T., and Mortier, A.: Optical properties and radiative forcing of the Eyjafjallajökull volcanic ash layer observed over Lille, France, in 2010, J. Geophys. Res., 117, D00U25, doi:10.1029/2011JD016815, 2012.

Devenish, B. J., Thomson, D. J., Marenco, F., Leadbetter, S. J., Ricketts, H., and Dacre, H. F.: A study of the arrival over the United Kingdom in April 2010 of the Eyjafjallajökull ash cloud using ground-based lidar and numerical simulations, Atmos. Environ., 148, 152-164, doi:10.1016/j.atmosenv.2011.06.033, 2012.

Dubovik, O., Sinyuk, A., Lapyonok, T., Holben, B. N., Mishenko, M., Yang, P., Eck, T. F., Volten, H., Munoz, O., Veihelmann, B., van der Zande, W. J., Leon, J.-F., Sorokin, M., and Slutsker, I.: Application of spheroid models to account for aerosol particle nonsphericity in remote sensing of desert dust, J. Geophys. Res., 111, D11208, doi:10.1029/2005JD006619, 2006.

Eck, T. F., Holben, B. N., Reid, J. S., Dubovik, O., Smirnov, A., O'Neill, N. T., Slutsker, I., and Kinne, S.: Wavelength dependence of the optical depth of biomass burning, urban, and desert dust aerosols, J. Geophys. Res., 104, 31333-31349, 1999.

Emeis, S., Forkel, R., Junkermann, W., Schäfer, K., Flentje, H., Gilge, S., Fricke, W., Wiegner, M., Freudenthaler, V., Gro $\beta$, S., Ries, L., Meinhardt, F., Birmili, W., Münkel, C., Obleitner, F., and Suppan, P.: Measurement and simulation of the $16 / 17$ April 2010 Eyjafjallajökull volcanic ash layer dispersion in the northern Alpine region, Atmos. Chem. Phys., 11, 2689-2701, doi:10.5194/acp-11-2689-2011, 2011.

Flentje, H., Claude, H., Elste, T., Gilge, S., Köhler, U., PlassDülmer, C., Steinbrecht, W., Thomas, W., Werner, A., and Fricke, W.: The Eyjafjallajökull eruption in April 2010 - detection of volcanic plume using in-situ measurements, ozone sondes and lidar-ceilometer profiles, Atmos. Chem. Phys., 10, 10085-10092, doi:10.5194/acp-10-10085-2010, 2010.

Gasteiger, J., Groß, S., Freudenthaler, V., and Wiegner, M.: Volcanic ash from Iceland over Munich: mass concentration retrieved from ground-based remote sensing measurements, Atmos. Chem. Phys., 11, 2209-2223, doi:10.5194/acp-11-22092011, 2011.

Gross, S., Freudenthaler, V., Wiegner, M., Gasteiger, J., Geiss, A., and Schnell, F.: Dual-wavelength linear depolarization ratio of volcanic aerosols: lidar measurements of the Eyjafjallajökull plume over Maisach, Germany, Atmos. Environ., 48, 8596, 2012.

Harris, A. J. L., Gurioli, L., Hughes, E. E., and Lagreulet, S.: Impact of the Eyjafjallajökull ash cloud: A newspaper perspective, J. Geophys. Res., 117, B00C08, doi:10.1029/2011JB008735, 2012.

Holben, B. N., Eck, T. F., Slutsker, I., Tanré, D., Buis, J. P., Setzer, A., Vermote, E., Reagan, J. A., Kaufman, Y. J., Nakajima, T., Lavenu, F., Jankowiak, I., and Smirnov, A.: AERONET-A federated instrument network and data archive for aerosol characterization, Remote Sens. Environ., 66, 1-16, doi:10.1016/S0034-
4257(98)00031-5, 1998.

Kaminski, E., Tait, S., Ferrucci F., Martet, M., Hirn, B., and Husson, P.: Estimation of ash injection in the atmosphere by basaltic volcanic plumes: the case of the Eyjafjallajökull 2010 eruption, J. Geophys. Res., 116, B00C02, doi:10.1029/2011JB008297, 2011.

Klett, J.: Lidar inversion with variable backscatter to extinction ratios, Appl. Optics, 24, 1638-1643, 1985.

Kokkalis, P., Papayannis, A., Mamouri, R. E., Tsaknakis, G., and Amiridis, V.: The EOLE lidar system of the National Technical University of Athens, Reviewed and revised papers presented at the 26th International Laser Radar Conference, 25-29 June 2012, Porto Heli, Greece, 629-632, 2012.

Kristiansen, N. I., Stohl, A., Prata, A. J., Bukowiecki, N., Dacre, H., Eckhardt, S., Henne, S., Hort, M. C., Johnson, B. T., Marenco, F., Neninger, B., Reitebuch, O., Seibert, P., Thomson, D. J., Webster, H. N., and Weinzierl, B.: Performance assessment of a volcanic ash transport model mini-ensemble used for inverse modeling of the 2010 Eyjafjallajökull eruption, J. Geophys. Res., 117, D00U11, doi:10.1029/2011JD016844, 2012.

Lathem, T. L., Kumar, P., Nenes, A., Dufek, J., Sokolik, I. N., Trail, M., and Russell, A.: Hygroscopic properties of volcanic ash, Geophys. Res. Lett., 38, L11802, doi:10.1029/2011GL047298, 2011.

Lettino, A., Caggiano, R., Fiore, S., Macchiato, M., Sabia, S., and Trippetta, S.: Eyjafjallajökull volcanic ash in southern Italy, Atmos. Environ., 48, 97-103, doi:10.1016/j.atmosenv.2011.05.037, 2012.

Mamouri, R. E., Papayannis, A., and Tsaknakis, G.: First water vapor measurements over Athens, Greece, obtained by a combined Raman-elastic backscatter lidar system, Opt. Pura Appl., 41, 109-116, 2008.

Matthias, V., Freudenthaler, V., Amodeo, A., Balin, I., Balis, D., Bösenberg, J., Chaikovsky, A., Chourdakis, G., Comeron, A., Delaval, A., De Tomasi, F., Eixmann, R., Hågård, A., Komguem, L., Kreipl, S., Matthey, R., Vincenzo, R., Rodrigues, J. A., Wandinger, U., and Wang, X.: Aerosol lidar inter-comparison in the framework of the EARLINET project. 1. Instruments, Appl. Optics, 43, 961-976, 2004.

Matthias, V., Aulinger, A., Bieser, J., Cuesta, J., Geyer, B., Langmann, Bärbel, Serikov, I., Mattis, I., Minikin, A., Mona, L., Quante, M., Schumann, U., and Weinzierl, B.: The ash dispersion over Europe during the Eyjafjallajökull eruption - comparison of CMAQ simulations to remote sensing and airborne in-situ observations, Atmos. Environ., 48, 184-194, doi:10.1016/j.atmosenv.2011.06.077, 2012.

Mattis, I., Ansmann, A., Müller, D., Wandinger, U., and Althausen, D.: Dual-wavelength Raman lidar observations of the extinction to-backscatter ratio of Saharan dust, Geophys. Res. Lett., 29, 1306, doi:10.1029/2002GL014721, 2002.

Millington, S. C., Saunders, R. W., Francis, P. N., and Webster, H. N.: Simulated volcanic ash imagery: A method to compare NAME ash concentration forecasts with SEVIRI imagery for the Eyjafjallajökull eruption in 2010, J. Geophys. Res., 117, D00U17, doi:10.1029/2011JD016770, 2012.

Mishchenko, M. I., Travis, L. D., Kahn, R. A., and West, R. A.: Modeling phase functions for dustlike tropospheric aerosols using a shape mixture of randomly oriented polydisperse spheroids, J. Geophys. Res., 102, 16831-16847, doi:10.1029/96JD02110, 1997. 
Mona, L., Amodeo, A., Pandolfi, M., and Pappalardo, G.: Saharan dust intrusions in the Mediterranean area: three years of Raman lidar measurements, J. Geophys. Res., 111, D16203, doi:10.1029/2005JD006569, 2006.

Mona, L., Amodeo, A., D’Amico, G., Giunta, A., Madonna, F., and Pappalardo, G.: Multi-wavelength Raman lidar observations of the Eyjafjallajökull volcanic cloud over Potenza, Southern Italy, Atmos. Chem. Phys., 12, 2229-2244, doi:10.5194/acp-12-22292012, 2012a.

Mona, L., Müller, D., Omar, A., Papayannis, A., Pappalardo, G., Sugimoto, N., and Vaughan, M.: Lidar measurements for desert dust characterization: A Review, Advances in Meteorology, 2012, ID356265, doi:10.1155/2012/356265, 2012b.

Müller, D., Wandinger, U., and Ansmann, A.: Microphysical particle parameters from extinction and backscatter lidar data by inversion with regularization: theory, Appl. Optics, 38, 2346-2357, 1999.

Müller, D., Veselovskii, I., Kolgotin, A., Tesche, M., Ansmann, A., and Dubovik, O.: Vertical profiles of pure dust (SAMUM-1) and mixed-smoke-dust plumes (SAMUM-2) inferred from inversion of multi-wavelength Raman/polarization lidar data and comparison to AERONET retrievals, Appl. Optics, 14, 3178-3202, 2013.

Näslund, E. and Thaning, L.: On the settling velocity in a non stationary atmosphere, Aerosol Sci. Technol., 14, 247-256, doi:10.1080/02786829108959487, 1991.

Navas-Guzmán, F., Müller, D., Bravo-Aranda, J. A., GuerreroRascado, J. L., Granados-Muñoz, M. J., Pérez-Ramírez, D., Olmo, F. J., and Alados-Arboledas, L.: Eruption of the Eyjafjallajökull volcano in spring 2010: Multiwavelength Raman lidar measurements of sulphate particles in the lower troposphere, J. Geophys. Res., 118, 2013, doi:10.1002/jgrd.50116, 2013.

Papayannis, A., Mamouri, R. E., Amiridis, V., Giannakaki, E., Veselovskii, I., Kokkalis, Tsaknakis, G., Balis, D., Kristiansen, N. I., Stohl, A., Korenskiy, M., Allakhverdiev, K., Huseyinoglu, M. F., and Baykara, T.: Optical properties and vertical extension of ash layers over the Eastern Mediterranean as observed by Raman lidars during the Eyjafjallajökull eruption (May 2010), Atmos. Environ., 48, 56-65, 2012.

Pappalardo, G., Amodeo, A., Wandinger, U., Matthias, V., Bösenberg, J., Alpers, M., Amiridis, V., de Tomasi, F., Frioux, M., Iarlori, M., Komguen, L., Larcheveque, G., Papayannis, A., Schumacher, R., and Wang, X.: Aerosol lidar intercomparison in the frame of EARLINET: Part III: Aerosol extinction Raman lidar algorithm intercomparison, Appl. Optics, 43, 5370-5385, 2004.

Pappalardo, G., Mona, L., D’Amico, G., Wandinger, H., Adam, M., Amodeo, A., Ansmann, A., Apituley, A., Alados Arboledas, L., Balis, D., Boselli, A., Bravo-Aranda, J. A., Chaikovsky, A., Comeron, A., Cuesta, J., De Tomasi, F., Freudenthaler, V., Gausa, M., Giannakaki, E., Giehl, H., Giunta, A., Grigorov, I., Groß, S., Haeffelin, M., Hiebsch, A., Iarlori, M., Lange, D., Linne, H., Madonna, F., Mattis, I., Mamouri, R.-E., McAuliffe, M. A. P., Mitev, V., Molero, F., Navas-Guzman, F., Nicolae, D., Papayannis, A., Perrone, M. R., Pietras, C., Pietruczuk, A., Pisani, G., Preißler, J., Pujadas, M., Rizi, V., Ruth, A. A., Schmidt, J., Schnell, F., Seifert, P., Serikov, I., Sicard, M., Simeonov, V., Spinelli, N., Stebel, K., Tesche, M., Trickl, T., Wang, X., Wagner, F., Wiegner, M., and Wilson, K. M.: Four-dimensional distribution of the 2010 Eyjafjallajökull volcanic cloud over Europe observed by EARLINET, Atmos. Chem. Phys., 13, 4429-4450, doi:10.5194/acp-13-4429-2013, 2013.

Prata, A. J. and Prata, A. T.: Eyjafjallajökull volcanic ash concentrations determined using spin enhanced visible and infrared imager measurements, J. Geophys. Res., 117, D00U23, doi:10.1029/2011JD016800, 2012.

Rauthe-Schöch, A., Weigelt, A., Hermann, M., Martinsson, B. G., Baker, A. K., Heue, K.-P., Brenninkmeijer, C. A. M., Zahn, A., Scharffe, D., Eckhardt, S., Stohl, A., and van Velthoven, P. F. J.: CARIBIC aircraft measurements of Eyjafjallajökull volcanic clouds in April/May 2010, Atmos. Chem. Phys., 12, 879-902, doi:10.5194/acp-12-879-2012, 2012.

Revuelta, M. A., Sastre, M., Fernández, A. J., Martín, L., García, R., Gómez-Moreno, F. J., Artíñano, B., Pujadas, M., and Molero, F.: Characterization of the Eyjafjallajökull volcanic plume over the Iberian Peninsula by lidar remote sensing and ground-level data collection, Atmos. Environ., 48, 46-55, doi:10.1016/j.atmosenv.2011.05.033, 2012.

Rolf, C., Krämer, M., Schiller, C., Hildebrandt, M., and Riese, M.: Lidar observation and model simulation of a volcanic-ashinduced cirrus cloud during the Eyjafjallajökull eruption, Atmos. Chem. Phys., 12, 10281-10294, doi:10.5194/acp-12-102812012, 2012.

Sanderson, K.: Out of the ashes, Nature, 465, 544-545, doi:10.1038/465544a, 2010.

Schleicher, N., Kramar, U., Dietze, V., Kaminski, U., and Norra, S.: Geochemical characterization of single atmospheric particles from the Eyjafjallajökull volcano eruption event collected at ground-based sampling sites in Germany, Atmos. Environ., 48, 113-121, doi:10.1016/j.atmosenv.2011.05.034, 2012.

Schumann, U., Weinzier, B., Reitebuch, O., Schlager, H., Minikin, A., Forster, C., Baumann, R., Sailer, T., Graf, K., Mannstein, H., Voigt, C., Rahm, S., Simmet, R., Scheibe, M., Lichtenstern, M., Stock, P., Rüba, H., Schäuble, D., Tafferner, A., Rautenhaus, M., Gerz, T., Ziereis, H., Krautstrunk, M., Mallaun, C., Gayet, J.F., Lieke, K., Kandler, K., Ebert, M., Weinbruch, S., Stohl, A., Gasteiger, J., Olafsson, H., and Sturm, K.: Airborne observations of the Eyjafjalla volcano ash cloud over Europe during air space closure in April and May 2010, Atmos. Chem. Phys., 11, 22452279, 2011,

http://www.atmos-chem-phys.net/11/2245/2011/.

Showstack, R.: Eruptions of Eyjafjallajökull volcano, Iceland, EOS Trans. Am. Geophys. Union, 91, 190-191, doi:10.1029/2010EO210002, 2010.

Sicard, M., Guerrero-Rascado, J. L., Navas-Guzmán, F., Preißler, J., Molero, F., Tomás, S., Bravo-Aranda, J. A., Comerón, A., Rocadenbosch, F., Wagner, F., Pujadas, M., and Alados-Arboledas, L.: Monitoring of the Eyjafjallajökull volcanic aerosol plume over the Iberian Peninsula by means of four EARLINET lidar stations, Atmos. Chem. Phys., 12, 3115-3130, doi:10.5194/acp-12-31152012, 2012.

Stohl, A., Hittenberger, M., and Wotawa, G.: Validation of the Lagrangian particle dispersion model FLEXPART against large scale tracer experiment data, Atmos. Environ., 32, 4245-4264, 1998.

Stohl, A., Forster, C., Frank, A., Seibert, P., and Wotawa, G.: Technical note: The Lagrangian particle dispersion model FLEXPART version 6.2, Atmos. Chem. Phys., 5, 2461-2474, doi:10.5194/acp-5-2461-2005, 2005. 
Stohl, A., Prata A. J., Eckhardt, S., Clarisse, L., Durant, A., Henne, S., Kristiansen, N. I., Minikin, A., Schumann, U., Seibert, P., Stebel, K., Thomas, H. E., Thorsteinsson, T., Tørseth, K., and Weinzierl, B.: Determination of time- and heightresolved volcanic ash emissions for quantitative ash dispersion modeling: The 2010 Eyjafjallajökull eruption, Atmos. Chem. Phys., 11, 4333-4351, doi:10.5194/acp-11-4333-2011, 2011.

Tesche, M., Ansmann, A., Müller, D., Althausen, D., Engelmann, R., Freudenthaler, V., and Groß, S.: Vertically resolved separation of dust and smoke over Cape Verde using multiwavelength Raman and polarization lidars during Saharan Mineral Dust Experiment 2008, J. Geophys. Res.-Atmos., 114, D13202, doi:10.1029/2009JD011862, 2009

Trickl, T., Giehl, H., Jäger, H., and Vogelmann, H.: 35 years of stratospheric aerosol measurements at Garmisch-Partenkirchen: from Fuego to Eyjafjallajökull, and beyond, Atmos. Chem. Phys. Discuss., 12, 23135-23193, doi:10.5194/acpd-12-23135-2012, 2012.

Tsekeri, A., Amiridis, V., Kokkalis, P., Basart, S., Chaikovsky, A., Dubovik, O., Mamouri, R. E., Papayannis, A., and Baldasano, J. M..: Application of synergetic lidar and sumphotometer algorithm for the characterization of a dust event over Athens, Greece, Brit. J. Environ. Climate Change, in review, 2013.

Veselovskii, I., Kolgotin, A., Griaznov, V., Müller, D., Wandinger, U., and Whiteman, D. N.: Inversion with regularization for the retrieval of tropospheric aerosol parameters from multi-wavelength lidar sounding, Appl. Optics, 41, 3685-3699, 2002.

Veselovskii, I., Whiteman, D. N., Kolgotin, A., Andrews, E., and Korenskii, M.: Demonstration of aerosol property profiling by multi-wavelength lidar under varying relative humidity conditions, J. Atmos. Ocean. Tech., 26, 1543-1557, 2009.

Veselovskii, I., Dubovik, O., Kolgotin, A., Lapyonok, T., Di Girolamo, P., Summa, D., Whiteman, D. N., Mishchenko, M., and Tanré, D.: Application of randomly oriented spheroids for retrieval of dust particle parameters from multi-wavelength lidar measurements, J. Geophys. Res., 115, D21203, doi:10.1029/2010JD014139, 2010.
Veselovskii, I., Dubovik, O., Kolgotin, A., Korenskiy, M., Whiteman, D. N., Allakhverdiev, K., and Huseyinoglu, F.: Linear estimation of particle bulk parameters from multi-wavelength lidar measurements, Atmos. Meas. Tech., 5, 1135-1145, doi:10.5194/amt-5-1135-2012, 2012.

Wagner, J., Ansmann, A., Wandinger, U., Seifert, P., Schwarz, A., Tesche, M., Chaikovsky, A., and Dubovik, O.: Evaluation of the Lidar/Radiometer Inversion Code (LIRIC) to determine microphysical properties of volcanic and desert dust, Atmos. Meas. Tech., 6, 1707-1724, doi:10.5194/amt-6-1707-2013, 2013.

Weber, K., Eliasson, J., Vogel, A., Fischer, C., Pohl, T., van Haren, G., Meier, M., Grobety, B., and Dahmann, D.: Airborne in-situ investigations of the Eyjafjallajökull volcanic ash plume on Iceland and over borth-western Germany with light aircrafts and optical particle counters, Atmos. Environ., 48, 9-21, 2012.

Webley, P. W., Steensen, T., Stuefer, M., Grell, G., Freitas, S., and Pavolonis, M.: Analyzing the Eyjafjallajökull 2010 eruption using satellite remote sensing, lidar and WRF-Chem dispersion and tracking model, J. Geophys. Res., 117, D00U26, doi:10.1029/2011JD016817, 2012.

Wiegner, M., Gasteiger, J., Groß, S., Schnell, F., Freudenthaler, V., and Forkel, R.: Characterization of the Eyjafjallajökull ashplume: Potential of lidar remote sensing, Phys. Chem. Earth, 4546, 79-86, doi:10.1016/j.pce.2011.01.006, 2012.

Winker, D. M., Liu, A., Omar, A., Tackett, J., and Fairlie, D.: CALIOP observations of the transport of ash from the Eyjafjallajökull volcano in April 2010, J. Geophys. Res., 117, D00U15, doi:10.1029/2011JD016499, 2012. 